\title{
n-3 Polyunsaturated fatty acids throughout the cancer trajectory: influence on disease incidence, progression, response to therapy and cancer-associated cachexia
}

\author{
Vickie E. Baracos ${ }^{1 *}$, Vera C. Mazurak ${ }^{1}$ and David W. L. Ma ${ }^{2}$ \\ ${ }^{1}$ Department of Oncology, Division of Palliative Medicine, University of Alberta, Edmonton, Alberta, Canada T6G 2P5 \\ ${ }^{2}$ Faculty of Nutrition, Texas A\&M University, College Station, Texas, USA
}

\begin{abstract}
Evidence from epidemiological studies suggests that diets rich in $n-3$ PUFA may be associated with reduced cancer risk. These observations have formed the rationale for exploring the mechanisms by which $n$-3 PUFA may be chemoprotective and have resulted in significant advances in our mechanistic understanding of $n$-3 PUFA action on tumour growth. Various interrelated and integrated mechanisms may be at work by which $n$ - 3 PUFA influence cancer at all stages of initiation, promotion, progression, and neoplastic transformation. More recently, experimental studies have reported enhanced tumour cell death with chemotherapy when fish oil is provided while toxic side effects to the host are reduced. Furthermore, cancer-associated wasting has been shown to be attenuated by fish oil supplementation. Clinical evidence suggests that the $n-3$ PUFA status of newly diagnosed cancer patients and individuals undergoing chemotherapy is low. Therefore, both the disease itself and therapeutic treatments may be contributing factors in the decline of $n-3$ PUFA status. Dietary supplementation to maintain and replenish $n-3$ PUFA status at key points in the cancer disease trajectory may provide additional health benefits and an enhanced quality of life. The present review will focus on and critically examine current research efforts related to the putative anti-cancer effects of $n-3$ PUFA and their suggested ability to palliate cancer-associated and treatment-associated symptoms.
\end{abstract}

Cancer: Polyunsaturated fatty acids: Fish oil: Chemotherapy: Cachexia: Drug resistance

\section{Introduction}

Adults in Western countries consume on average 75 to $150 \mathrm{~g}$ and 30 to $45 \%$ of their total energy from fat, a smaller proportion of which consists of long-chain PUFA. The essential fatty acids, linoleic (18:2n-6) and $\alpha$ linolenic $(18: 3 n-3)$ acids, cannot be synthesised by mammalian cells, and so must be obtained from the diet. Linoleic acid can be elongated and desaturated to arachidonic acid whereas enzyme conversion from linolenic acid forms eicosapentaenoic acid (EPA; $20: 5 n-3)$ which can be further metabolised to docosahexaenoic acid (DHA; 22 : 6n-3). In Western diets, $n-6$ fatty acids are the predominant PUFA as they are widely distributed in most plant oils (for example, maize, safflower-seed, sunflower-seed), margarines, and animal fat, whereas dietary sources of $\alpha$ linolenic acid are comparatively limited. $\alpha$-Linolenic acid is found in flaxseed, soyabean and rapeseed oils. Long- chain n-3 PUFA, EPA and DHA, can be synthesised from $\alpha$-linolenic acid in man, and also consumed in the diet from marine fish oils (for example, herring, mackerel, tuna, sardine) and in the oils extracted from the livers of fish which live in warmer waters (for example, cod). The $n-6$ and $n-3$ fatty acids compete in biochemical pathways and have metabolically distinct and opposing physiological functions.

Epidemiological and experimental evidence link $n-3$ PUFA to reduced cancer risk. This work has centred on the anti-cancer effects of $n$-3 PUFA derived from fish oils containing EPA and DHA. Several recent reviews have addressed in detail the array of mechanisms attributable to $n-3$ PUFA to inhibit cancer growth during the initiation and promotion stages of cancer development (Jiang et al. 1998; Bartsch et al. 1999; Bougnoux, 1999; Rose \& Connolly, 1999b, 2000; Simopoulos, 1999, 2002; Woutersen et al. 1999; Stoll, 2001; Hardman, 2002; McEntee \& Whelan,

\footnotetext{
Abbreviations: COX, cyclo-oxygenase; DHA, docosahexaenoic acid; DOX, doxorubicin; EPA, eicosapentaenoic acid; MDR, multiple drug resistance; PgP, phosphoglycoprotein; PIF, proteolysis-inducing factor; PKC, protein kinase C.

* Corresponding author: Dr Vickie E. Baracos, fax +1 780432 8425, email Vickie.baracos@ualberta.ca
} 
2002; Chajes \& Bougnoux, 2003). An exciting new implication of $n-3$ PUFA use in cancer treatment has emerged in recent years from in vitro and animal studies that suggest a potential interaction between $n-3$ PUFA and cancer chemotherapy. $n$-3 PUFA have been reported to enhance chemotherapy-induced tumour cell death and also reduce the toxic side effects of chemotherapy on host tissues. Finally, cachexia is a common paraneoplastic syndrome and $n$-3 PUFA may interfere with the catabolic signal-transduction pathways implicated in cancer cachexia and attenuate the loss of weight and lean body mass in patients with advanced cancer (Barber \& Fearon, 2001; Ross \& Fearon, 2002). It is also important to note that neurotransmitters and hormones that may be involved in various stages of cancer progression, including disease-induced anorexia, have also been reported to be affected by $n-3$ fatty acids. However, this discussion is beyond the scope of the present paper and has been reviewed elsewhere (Meguid et al. 2000; Wang et al. 2002; Das et al. 2003; Laviano et al. 2003). In the light of suggestions that $n-3$ PUFA status in cancer patients may be poor, these beneficial effects of $n-3$ PUFA may underpin an argument for dietary supplementation to maintain and replenish $n-3$ PUFA status at key points in the cancer disease trajectory. The present review will focus on and critically examine current research efforts related to the putative anti-cancer effects of $n-3$ PUFA and their suggested ability to palliate cancer- and treatmentassociated symptoms.

\section{Dietary polyunsaturated fatty acids: prevention and risk reduction of cancer}

There are several prevailing streams of thought regarding the contribution of dietary fat to cancer. Animal studies in particular have allowed the delineation of these points through the use of diets with defined fat components. The quantity and energy contribution of fat to energy intake and the composition of that fat independently influence cancer risk and the growth of established tumours. Within fat composition, the importance of the PUFA:saturated fatty acids ratio in the diet as well as the levels of different specific fatty acids on tumour incidence, growth and anti-tumour immune responses have been recognised (Sasaki et al. 1998; Robinson et al. 2001). The balance between $n-3$ and $n$-6 PUFA is important, but this may also extend to other biologically active fatty acids such as conjugated linoleic acid (Wahle \& Heys, 2002), oleic acid (Bartsch et al. 1999), and individual fatty acids within the $n-3$ and $n-6$ PUFA family.

\section{Epidemiological and experimental evidence}

The results from epidemiological studies examining the effect of fish consumption on the development of human cancer has been reviewed extensively (de Deckere, 1999; Cohen, 2000; Weisburger, 2000; Zock, 2001; Temple, 2002; Dennis et al. 2003; Terry et al. 2003). Although studies suggest a beneficial and protective effect of fish oil consumption, overall, epidemiological evidence cannot be used to definitively conclude that $n-3$ PUFA consumption is chemoprotective. There are two significant shortcomings inherent in most epidemiological studies. Reviewed collectively, studies fail to demonstrate that cancer risk or tumour burden is lowered by $n-3$ PUFA consumption. Second, such approaches do not rigorously address mechanisms of action. The inconsistent findings reflect the difficulty in evaluating the relative contribution of minor fatty acids in the diet which are not easily dissected from a large matrix of confounders. The list of confounders appears endless and highlights the many challenges in interpreting these types of studies.

Given the recognised limitations of various epidemiological study formats (i.e. case-control, retrospective and prospective studies; Temple, 2002; Dennis et al. 2003), the fact remains that there is a trend that suggests a role for dietary $n-3$ PUFA in cancer prevention. Whereas the epidemiological data have primarily provided correlative evidence for cancer prevention and risk reduction, experimental data from animal models and cell lines demonstrate that dietary $n-3$ PUFA can inhibit tumour growth in a variety of cancer models such as breast, colon and prostate (Clarke $e t$ al. 1999; Connolly et al. 1999; Chen \& Istfan, 2000; Chung et al. 2001). A large body of in vitro and animal model data links $n$-3 PUFA to physiological and morphological changes that reduce tumour weight, size and multiplicity.

Various mechanisms may be at work by which $n-3$ PUFA can prevent cancer at all stages of initiation, promotion, progression, and then neoplastic transformation of benign tumours to malignant tumours. A survey of the literature reveals a multitude of mechanisms currently being investigated, broadly related to apoptosis, cell proliferation, cell signalling, gene regulation, angiogenesis and metastasis; these are summarised in Fig. 1. Well-studied mechanisms have been discussed in detail in several recent reviews (Jiang et al. 1998; Bartsch et al. 1999; Bougnoux, 1999; Rose \& Connolly, 1999b, 2000; Simopoulos, 1999, 2002; Woutersen et al. 1999; Stoll, 2001; Hardman, 2002; McEntee \& Whelan, 2002; Chajes \& Bougnoux, 2003); therefore, we will highlight, or summarise in brief, areas of emerging interest.

Apoptosis. There is keen interest to understand how $n-3$ PUFA may alter the balance between cell growth and cell death. Experimental evidence suggests that the absolute or relative levels of $n-6$ and $n-3$ PUFA can either promote tumour cell growth, or promote apoptosis, respectively. A variety of mechanisms may be involved in orchestrating apoptosis by $n$-3 PUFA (Fig. 1). Mitochondrial-mediated apoptosis is an important facet of programmed cell death (Ravagnan et al. 2002). An emerging area of importance is the involvement of $n-3$ PUFA in modulating mitochondrialmediated apoptosis regulated by the Bcl-2 family of proteins (Ravagnan et al. 2002). This family of proteins promotes and inhibits apoptosis by regulating the release of downstream effectors from the mitochondria. In rats fed fish or maize oil in combination with fibre, the combination of fish oil and fibre was shown to increase colonocyte mitochondrial membrane potential, cytochrome $\mathrm{C}$ release and caspase-3 activity, hallmarks of mitochondrial-mediated apoptosis (Hong et al. 2002). In a rat model of colon cancer, apoptosis was enhanced in fish-oil-fed animals which expressed lower levels of the anti-apoptotic protein, Bcl-2 


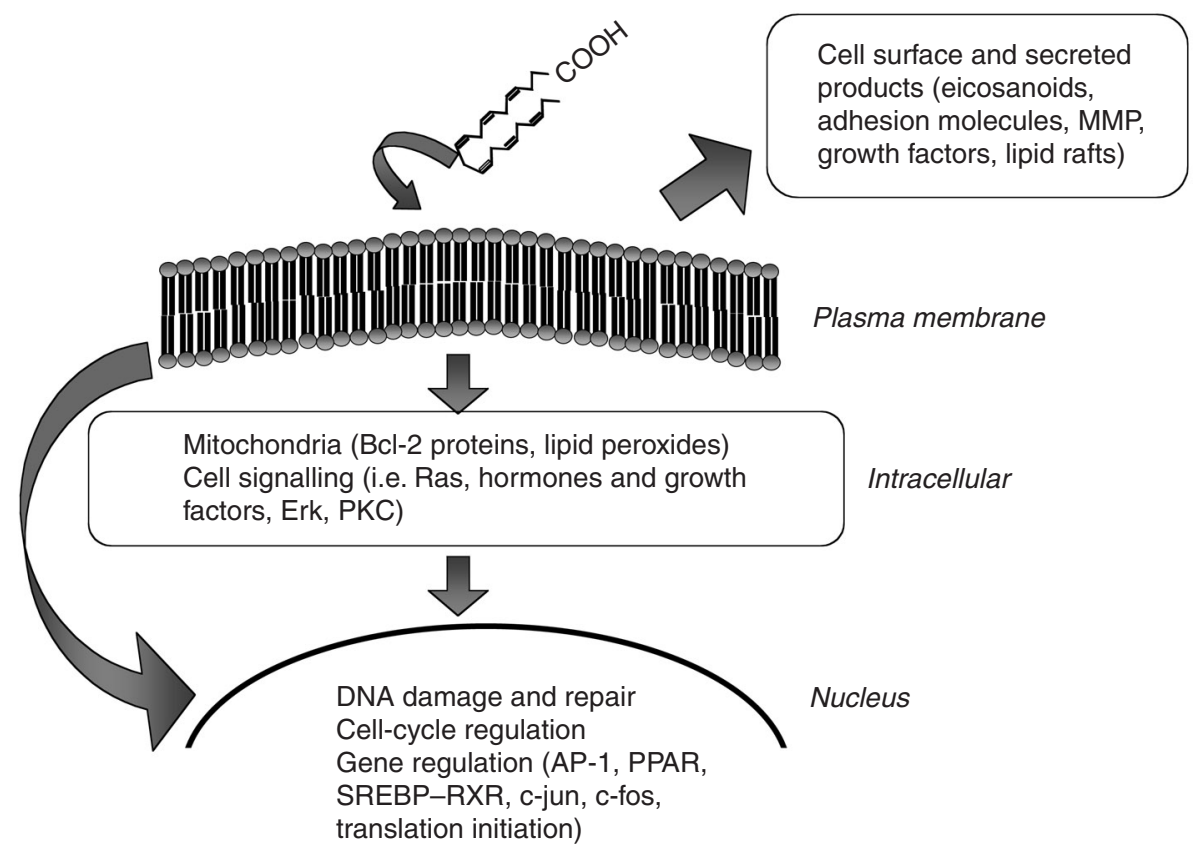

Fig. 1. $n-3$ PUFA can affect tumour biology at multiple levels of the plasma membrane, intracellular and nuclear compartments. Consequently, $n-3$ PUFA have effects on regulating apoptosis, cell proliferation, cell signalling, gene regulation, angiogenesis and metastasis. MMP, matrix metalloproteinase; Erk, extracellular-signal-regulated kinase; PKC, protein kinase C; AP, activator protein-1; PPAR, peroxisome proliferator activated receptor; SREBP, sterol regulatory element-binding protein; RXR, retinoid $X$ receptor.

(Hong et al. 2003). Yamamoto et al. (1999) reported that EPA enhances the expression of pro-apoptotic (Bax and $\mathrm{Bcl}-\mathrm{Xs}$ ) and reduces the expression of anti-apoptotic (Bcl-2 and Bcl-xL) proteins in mammary cancer cell lines. Studies in Jurkat leukaemic (Siddiqui et al. 2001) and HT-29 colonic (Clarke et al. 1999) tumour cell lines have shown that exposure to DHA and EPA enhanced caspase-3 activation, an activator of apoptosis. In colonic HT-29 cancer cells, Bcl-2 expression is strongly down regulated by DHA, which is in part mediated by increased lipid peroxidation (Chen \& Istfan, 2000). These studies provide new mechanistic insight into the action of $n-3$ PUFA, demonstrating the ability to shift the balance between pro- and anti-apoptotic Bcl-2 proteins in favour of cell death in cancer cells.

Cell signalling via lipid rafts and caveolae. A large number of research reports suggest that $n$-3 PUFA can modulate cell physiology by affecting signalling-transduction pathways and the expression of genes. A variety of signalling molecules such as protein kinase C (PKC; Pandian et al. 2001), Ras (Davidson et al. 1999; Collett et al. 2001), cellcycle proteins (Chen \& Istfan, 2001), eicosanoids (HughesFulford et al. 2001), transcription factors (Thoennes et al. 2000; Chung et al. 2001; Liu et al. 2001) and translation factors (Palakurthi et al. 2000) have been identified as cellular targets of $n$-3 PUFA (Fig. 1).

The integration and regulation of many cell-signalling events at the level of the plasma membrane is now known to involve structures known as lipid rafts and caveolae. Lipid rafts and caveolae are characterised as highly ordered microdomains of the plasma membrane enriched in choles- terol and sphingolipids (Liu et al. 2002; Pike et al. 2002; Pike, 2003). Many signal-transduction proteins are now known to preferentially localise to these microdomains. Altering the lipid composition of rafts has been reported to affect cell-signalling pathways (Swinnen et al. 2003) as well as the localisation, and hence functionality, of resident proteins. Incorporation of $n$-3 PUFA into lipid rafts of immune cells has been shown to profoundly disrupt T-cell receptor protein assemblage and functionality both in vitro (Stulnig et al. 1998, 2001) and in vivo (Fan et al. 2003). This suggests a mechanism by which $n$-3 PUFA can attenuate inflammatory processes. Therefore, modification of the lipid composition in these microdomains by $n-3$ PUFA may also have a significant effect on signalling pathways in cancer cells.

Angiogenesis and metastasis. There is some evidence suggesting that $n$-3 PUFA may be beneficial in inhibiting angiogenesis and metastasis; however, the exact mechanisms have yet to be clearly defined. At more progressive stages of tumour development $n-3$ PUFA have been reported to have anti-angiogenic effects in breast cancer (Rose \& Connolly, 1999a , 2000) and anti-metastatic effects in colon and breast cancer models (Iwamoto et al. 1998; Senzaki et al. 1998), preventing the formation of new blood vessels to support tumour growth and expansion to secondary sites. The mechanisms by which $n$-3 PUFA inhibit these processes are not known, but may involve NO synthesis (Narayanan et al. 2003), the synthesis of bioactive metabolites from $n$-3 PUFA (Tsuji et al. 2003), or lipoxygenase-derived metabolites (Pasqualini et al. 2003).

Overall, recent investigations have focused on the role of 
cyclo-oxygenase (COX) expression and the use of selective COX inhibitors as anti-angiogenic and anti-metastatic agents (Amano et al. 2003; Shappell et al. 2003; Woods et al. 2003; Yamauchi et al. 2003). The use of highly novel models, such as the prostaglandin receptor knockout mouse model, has identified a role for a prostaglandin receptor in angiogenesis (Amano et al. 2003). These studies demonstrate a role for COX and eicosanoids in tumour development. Moreover, these observations suggest an influential role for $n-3$ PUFA in modulating COX function and eicosanoid synthesis as a mechanism for inhibiting angiogenesis and metastasis; however, a clear beneficial effect has yet to be determined in man. In fact, there is evidence suggesting that $n$-3 PUFA have no effect on metastasis (Griffini et al. 1998). It is possible that there are limitations to the degree in which $n$-3 PUFA can be efficacious in affecting the outcome of very-late-stage tumour development. Further studies in this area are needed to address this potentially beneficial role of $n-3$ PUFA.

Gene regulation. We have briefly highlighted several possible mechanisms of action by which $n$-3 PUFA affect tumour growth, and one may question how it is possible for these elements to simultaneously result in diverse changes in cell metabolism. This is certainly a complex issue, as one realises that $n-3$ PUFA do not necessarily have to act at a single critical juncture in cell physiology to explain all the phenomenology. The accumulated experimental evidence so far has linked $n$-3 PUFA to very compartmentalised segments of inter-related and integrated biochemical processes. Therefore, understanding how integrated pathways and processes behave when $n-3$ PUFA are supplemented will be critical in substantiating the health benefits of $n-3$ PUFA in cancer. The advent of genomic technologies has created the potential for greater understanding of the mechanism of action. Microarray technologies now provide the capability to assess the expression of thousands of genes simultaneously, yielding a cancer expression profile (BirkenkampDemtroder et al. 2002; Mariadason et al. 2002; Rhodes et al. 2002). Only two microarray studies have been published on the chemoprotective effects of $n-3$ PUFA. Using Caco-2 colon cancer cells, microarray analyses revealed that apoptosis-, cell cycle-, NO- and eicosanoid-related genes were affected by $n-3$ PUFA treatment, consistent with a chemoprotective role of $n-3$ PUFA against colon cancer (Narayanan et al. 2001, 2003). These exciting studies are at the forefront of, and most probably foreshadow, more studies that will increase our understanding of $n-3$ PUFA effects at the molecular level. This provides the potential to identify relational interactions between genes that are either up regulated or down regulated in response to $n$-3 PUFA. Furthermore, genes previously not considered for their relevance or yet to be identified gene products, known affectionately as EST, can be identified for further study.

\section{n-3 Polyunsaturated fatty acids enhance anti-tumour effects of some chemotherapeutic agents}

A clearer understanding and subsequent exploitation of cell properties and proteins involved in apoptotic and proliferative pathways has led to the development of potent cyto- toxic agents effective at reducing tumour growth, but not without toxic side effects. The toxicity inherent in these drugs requires that dosages be limited and delivered in conjunction with adjuvant therapies or strategies to enhance the toxicity of drugs to tumour cells at low doses and/or offer protection to non-target tissues. $n$-3 PUFA are reported to exhibit both of these properties and therefore may be highly useful during cancer chemotherapy.

\section{Efficacy of chemotherapy and $\mathrm{n}-3$ polyunsaturated fatty acids}

Certain PUFA enhance the cytotoxicity of several widely used anti-neoplastic agents including anthracyclines, cisplatinum, alkylating agents, irinotecan and bleomycin (for a review, see Conklin, 2002). As is the case for cancer prevention and inhibition of cancer progression, there are potentially several inter-related and integrated mechanisms that impart benefits associated with anti-neoplastic therapies. To date, most of these studies have been performed in vitro and in animals (summarised in Table 1); however, a rationale may be forthcoming for movement of these observations to the clinic. This section will review the most recent literature that has investigated the interaction of $n-3$ PUFA with cytotoxic drugs for cancer treatments.

Membranes and proteins. Much of the recent work citing improved sensitivity to cytotoxic drugs has arisen from the investigations into how $n-3$ PUFA aid in overcoming multiple drug resistance (MDR). Inherent, or, more commonly, acquired MDR has been defined as cross resistance to a broad spectrum of structurally and functionally unrelated cytotoxic drugs (Davies et al. 1999) which render chemotherapy treatments ineffective. The ability of tumour cells to survive and adapt to unfavourable conditions is an inherent feature of malignancy and understanding the mechanisms of how this occurs may be useful in developing new targets of intervention. MDR is associated with several alterations in cellular properties including changes in drug transport (Cowan et al. 1986), overexpression of drug efflux pumps (Arancia et al. 2001) and elevated levels of antioxidant enzymes (Batist et al. 1986; Gottesman \& Pastan, 1993; Kumar \& Das, 1995; Abulrob et al. 2000). Importantly, compared with cell lines that are sensitive to chemotherapy drugs, drug-resistant cell lines differ in their ability to take up supplemental fatty acids (Davies et al. 1999) and exhibit lower $\alpha$-linolenic, $\gamma$-linolenic and DHA content in their membrane phospholipids (Das et al. 1998). Cells expressing MDR exhibit elevated levels of cholesterol, glycosphingomyelin and sphingomyelin in their cell membranes, lipids that are characteristically associated with membrane microdomains, caveolae and rafts (for reviews, see Lavie et al. 1999; Lavie \& Liscovitch, 2000; Senchenkov et al. 2001).

Experimental studies have shown that $n-3$ PUFA increase the cytotoxicity of several anti-neoplastic agents that work through diverse and varied mechanisms (Conklin, 2002), suggesting that there may be several means by which $n-3$ PUFA are able to modulate this response. The addition of fatty acids to media or to the diet results in their subsequent enrichment in membranes and tissues, including 
Table 1. Experimental studies of enhanced cytotoxicity of chemotherapy drugs by $n-3$ fatty acids

\begin{tabular}{|c|c|c|c|c|}
\hline Author & Model & Drug & Design & Main findings \\
\hline $\begin{array}{l}\text { Das et al. } \\
(1998)\end{array}$ & $\begin{array}{l}\text { Vincristine-resistant and } \\
\text {-sensitive HeLa variants } \\
\text { (KB-ChR-8-5 and KB-3-1) } \\
\text { human cervical carcinoma } \\
\text { cells }\end{array}$ & $\begin{array}{l}\text { Vincristine, } \\
\text { cisplatinum, and } \\
\text { doxorubicin }\end{array}$ & $\begin{array}{l}\text { Cells cultured with or without } \\
\text { fatty acids (DHA, } 20: 3 n-6, A A \text {, } \\
\text { EPA, } 18: 3 n-6,18: 2 n-6 \text { and } \\
18: 3 n-3) \\
\text { Cells were supplemented with } \\
10 \text { ng }\left[{ }^{3} \mathrm{H}\right] \text {-vincristine/ml. }\end{array}$ & $\begin{array}{l}\text { Increased cytotoxicity by } \\
18: 3 n-6 \text { and EPA } \\
\text { Increased uptake and retention } \\
\text { of vincristine by } 18: 3 n-3 ; \\
18: 3 n-6 \text { EPA- and DHA-treated } \\
\text { cells }\end{array}$ \\
\hline $\begin{array}{l}\text { Germain et al. } \\
\text { (1998) }\end{array}$ & $\begin{array}{l}\text { MDA-MB-231, breast cancer } \\
\text { cells }\end{array}$ & $\begin{array}{l}\text { DOX and } \\
\text { Mitoxantrone }\end{array}$ & $\begin{array}{l}\text { Cells supplemented with EPA, } \\
\text { DHA, } 20: 4 n-6,18: 3 n-6 \text {, } \\
18: 3 n-3,18: 2 n-6 \text { or } 18: 1 n-9 \\
\text { with and without oxidants }\end{array}$ & $\begin{array}{l}\text { Increased DOX cytotoxicity by } \\
\text { DHA and further increase by } \\
\text { addition of oxidants }\end{array}$ \\
\hline $\begin{array}{l}\text { Davies et al. } \\
\text { (1999) }\end{array}$ & $\begin{array}{l}\text { Anthracycline-sensitive and } \\
\text {-resistant breast (MCF-7) } \\
\text { and urothelial (MGH-U1) } \\
\text { cell lines }\end{array}$ & $\begin{array}{l}\text { Anthracyclines and } \\
\text { related drugs: } \\
\text { DOX; epitoposide; } \\
\text { idarubicin } \\
\text { methotrexate }\end{array}$ & $\begin{array}{l}\text { Incubated with } 18: 3 n-6 \text { for } \\
24 \mathrm{~h} \text { before drug treatment. } \\
\text { Flow cytometry and confocal } \\
\text { microscopy assessed drug } \\
\text { uptake and localisation }\end{array}$ & $\begin{array}{l}\text { Flow cytometry showed no } \\
\text { increase in drug uptake } \\
\text { with } 18: 3 n-6 \text { treatment. } \\
\text { Increase in idarubicin } \\
\text { uptake in resistant cell } \\
\text { lines treated with } 18: 3 n-6 \\
\text { using confocal microscopy }\end{array}$ \\
\hline $\begin{array}{l}\text { Hardman et al. } \\
(2000) ;\end{array}$ & $\begin{array}{l}\text { Nude mice injected with } \\
\text { A549 lung tumour cells }\end{array}$ & & $\begin{array}{l}\text { Maize oil }(20 \%) \text { or fish oil }(19 \%+ \\
1 \% \text { maize oil) diets. }\end{array}$ & $\begin{array}{l}\text { Increased tumour regression by } \\
\text { fish oil }\end{array}$ \\
\hline $\begin{array}{l}\text { Liu \& Tan } \\
(2000)\end{array}$ & $\begin{array}{l}\text { P388 and P388/DOX- } \\
\text { resistant mouse leukaemia } \\
\text { cell line }\end{array}$ & DOX & $\begin{array}{l}\text { Cells treated with combinations of } \\
18: 3 n-6, \mathrm{DHA}, \mathrm{DOX} \text { and } \\
\text { antioxidants }\end{array}$ & $\begin{array}{l}\text { Following pretreatment of cells } \\
\text { with } 18: 3 n-6 \text { or DHA: sensitivity } \\
\text { to DOX in resistant cells; } \\
\text { increase in some antioxidant } \\
\text { enzyme activities in cells } \\
\text { Addition of antioxidants to media } \\
\text { reduced level of antioxidant } \\
\text { enzymes to normal }\end{array}$ \\
\hline $\begin{array}{l}\text { Bradley et al. } \\
(2001)\end{array}$ & $\begin{array}{l}\text { Madison } 109 \text { (M109) small- } \\
\text { cell lung tumours in } \\
\text { CD2F1 mice }\end{array}$ & $\begin{array}{l}\text { DHA-paclitaxel } \\
\text { conjugate or } \\
\text { paclitaxel }\end{array}$ & $\begin{array}{l}\text { Drugs were administered } \\
\text { (intravenously) once daily } \\
\text { for } 5 \mathrm{~d}\end{array}$ & $\begin{array}{l}\text { No regression with paclitaxel } \\
\text { alone; increased regression with } \\
\text { conjugate; increased retention of } \\
\text { paclitaxel in cells by conjugate }\end{array}$ \\
\hline \multicolumn{2}{|c|}{$\begin{array}{l}\text { Menendez et al. Breast cancer cells } \\
\begin{array}{l}\text { (2001) } \\
\text { (MDA-MB-231, SK-Br3, } \\
\text { T47D and MCF-7) }\end{array}\end{array}$} & $\begin{array}{l}\text { Paclitaxel, vinorelbine } \\
\text { (navelbine) and } \\
\text { gemcitabine }\end{array}$ & $\begin{array}{l}\text { Cells supplemented with } \\
\text { paclitaxel alone or with fatty } \\
\text { acids }(18: 1 n-9,18: 2 n-6, \\
18: 3 n-3,18: 3 n-6, \text { EPA or } \\
\text { DHA) before and after } \\
\text { paclitaxel treatment }\end{array}$ & $\begin{array}{l}\text { Increased drug cytotoxicity in the } \\
\text { following order: } 18: 3 n-6> \\
18: 3 n-3>20: 5 n-3> \\
22: 6 n-3>\text { LA }=\text { paclitaxel alone. } \\
\text { Increased cytotoxicity of navel- } \\
\text { bine, but not gemcitabine by } 1 \\
18: 3 n-6\end{array}$ \\
\hline $\begin{array}{l}\text { Yam et al. } \\
(2001)\end{array}$ & $\begin{array}{l}\text { C57 BL/6J mice inoculated } \\
\text { with Lewis lung carcinoma }\end{array}$ & Cisplatin & $\begin{array}{l}\text { Dietary treatments comprised } \\
\text { chow, fish oil }(4 \%) \text {, with or } \\
\text { without antioxidants. Diets were } \\
\text { fed before tumour inoculation } \\
\text { and fish oil diet switched to an } \\
\text { antioxidant-supplemented diet } \\
\text { after cisplatin treatment }\end{array}$ & $\begin{array}{l}\text { Decreased metastasis with fish oil } \\
\text { diet; decreased metastasis } \\
\text { following cisplatin treatment } \\
\text { was achieved with antioxidant- } \\
\text { and fish-oil-supplemented diets }\end{array}$ \\
\hline
\end{tabular}

DHA, docosaexaenoic acid; AA, arachidonic acid; EPA, eicosapentaenoic acid; DOX, doxorubicin; LA, linoleic acid.

tumour cells (Hardman et al. 2000). A more fluid membrane may allow for greater influx (Siegfried et al. 1985), enhanced uptake (Spector \& Burns, 1987) or increased permeability (Menendez et al. 2001) of drugs resulting in increased intracellular drug concentrations. Increasing the effectiveness of anti-neoplastic agents to cancer cells may first require that supplemental $n-3$ PUFA are able to alter the membrane composition of malignant cells. The mechanism by which the efficacy of cytotoxic drugs is increased may be, in part, determined by the mechanism of the drug in question. The studies that have emerged exemplify the importance of determining the types of tumour-drug combinations that may be most responsive to interventions with $n-3$ PUFA (Table 1).
Phosphoglycoprotein $(\mathrm{PgP})$ is a transporter whose activity is highly influenced by the lipid microenvironment (Lavie \& Liscovitch, 2000). PgP facilitates the movement of cytotoxic drugs out of the cell (Abulrob et al. 2000) and is overexpressed in MDR (Goldstein et al. 1992; Gottesman \& Pastan, 1993). While this protein has been identified as a target for drug development, at present, agents known to modify the action of PgP, such as doxorubicin (DOX), are not potent enough at the doses required to avoid toxic effects (Sikic, 1997). n-3 PUFA have been reported to increase the accumulation and retention of DOX in both drug-resistant and drug-sensitive cell lines via a PgP-dependent mechanism (Rudra \& Krokan, 2001). PKC is the intracellular pathway that phosphorylates and acti- 
vates PgP. Tumours exhibiting MDR have been reported to exhibit higher PKC activity (Das et al. 1998; Cha et al. 2001); this offers an additional target for novel cytotoxic drugs. For example, some genotoxic drugs work by reducing PKC activity (Cha et al. 2002). EPA and DHA are known modulators of the PKC activation pathway (Nakamura \& Nishizuka, 1994; Verstovsek et al. 1998; Mirnikjoo et al. 2001; Nair et al. 2001) and subsequently may alter the function of other proteins and enzymes that rely on this intracellular pathway. Whether or not $n-3$ PUFA are effective in overcoming MDR via a PKC-related mechanism is beginning to be explored.

Other cell types exhibiting MDR show reduced levels of p53, a cell-cycle inhibitor (Das et al. 1998; Davies et al. 1999; Menendez et al. 2001) that is an essential component of the apoptotic process induced by anti-cancer drugs. Tumours that do not express p53 are resistant to therapies and continue to grow. Drugs have been developed to up regulate p53 expression in tumours to make them more sensitive to treatment (Davies et al. 1999). The interaction of these drugs with $n$-3 PUFA has not yet been explored and may hold promise in future experimental studies.

\section{Formation of peroxides}

Several lines of evidence have evolved to support a role for PUFA in promoting an oxidative environment in the presence of cytotoxic drugs to create an environment toxic to tumour cells (for a review, see Conklin, 2002). Recent literature has confirmed previous reports that the supplementation of $n-3$ fatty acids reduces the expression of endogenous antioxidant enzymes in tumours both in vitro (Davies et al. 1999) and in an animal model (Hardman et al. 2001), thereby creating the potential for the development of a more oxidative environment. Suppressing enzymes such as glutathione peroxidase in the tumour has been reported to be a more important factor in reducing tumour growth than the formation of peroxides induced by the drug (Hardman et al. 2002).

Despite the evidence for a role of peroxidation in promoting tumour death (Germain et al. 1998; Cognault et al. 2000; Menendez et al. 2001; Yam et al. 2001), not all studies support these findings (Rudra \& Krokan, 2001). Cytotoxic effects of acrolein, a metabolite of the cytostatic drug cyclophosphamide, were not related to lipid peroxidation in a glioblastoma cell line even though oxidative damage occurred in a lung tumour cell line in the same study (Rudra \& Krokan, 2001). Another study reported that the addition of $18: 3 n-6$ and DHA to P388 cells increased the expression of tumour antioxidant enzymes, an effect that was abrogated by adding antioxidants to the media (Liu \& Tan, 2000). Differences in the timing of administration of fish oil and/or antioxidants, the type of drug used and the characteristics of the cell lines employed may explain the inconsistent reports. Drug-sensitive and -resistant cell lines have been reported to respond differently to an oxidative environment and also differ in their ability to take up supplemental fatty acids into their membranes as well as their ability to up regulate antioxidant enzymes to protect against peroxidation (Kumar \& Das, 1995). Further work is needed to define the optimal oxidative environment for promoting tumour cell death in the presence of fish oil. In a highly oxidative environment, such as that induced by some cytotoxic agents, supplemental fatty acids may be oxidised before they are incorporated into tumours (Yam et al. 2001), thereby reducing their mechanism of action. On the other hand, supplementing antioxidants to the host before treatment may reduce peroxidation intended by the drug. Studies employing diets that contain low amounts of PUFA have reported no effect on tumour growth and number when oxidative agents are utilised (Cognault et al. 2000). Therefore, lipid peroxidation as a mechanism of enhanced tumour death may only be relevant in the presence of high amounts of dietary PUFA. Feeding a fish oil-enriched diet fed before and supplementing with vitamins $\mathrm{E}$ and $\mathrm{C}$ after cyclophosphamide treatment was reported to have the most effective anti-metastatic effect in an animal model (Yam et al. 2001). Hrelia et al. (2002) reported that extracts derived from green tea, which act as antioxidants, counteract the membrane modification of cardiomyocytes induced by DOX and argue a point for the concurrent supplementation of $n$-3 PUFA and antioxidants. Taken together, these studies emphasise the possible importance of the oxidative status of the host before, during and after cytotoxic treatments as additional potential factors involved in tumour cytotoxicity. It is of note that many toxic side effects, such as cardiotoxicity, mutagenesis, pulmonary fibrosis, neutropenia, reduced natural killer cell activity, anorexia and cachexia (Clemens et al. 1997; Sidorenko et al. 1998; Theile \& Kemper, 1998), are related to the exhaustion of built-in host antioxidant mechanisms following chemotherapy treatment. It would seem important to further clarify the optimal conditions for enhanced cytotoxic effects to the tumour while preventing harmful side effects by adjusting the redox balance of the host. Results from the diverse models and agents that are being actively investigated (Table 1) will provide insight into how fish oils alter tumour biology and interact with diverse anti-neoplastic agents.

\section{n-3 Fatty acids and palliation of cancer: associated symptoms}

\section{n-3 Polyunsaturated fatty acids limit the toxic side effects of chemotherapy}

Gastrointestinal, haematological and cardiac toxicities limit the dose at which anti-cancer drugs can be administered. Chemotherapy regimens are toxic, and significant numbers of patients experience sufficient toxicity to have their doses reduced and/or delayed or require hospitalisation for toxic side effects. Several recent studies report an association between dietary fish oil supplementation and the attenuation of side effects associated with anti-neoplastic therapies (summarised in Table 2).

In a series of cell culture and animal studies, Hardman et al. (1999, 2000, 2001, 2002) have accumulated evidence to support a protective effect of fish oil on host tissues during chemotherapy. CPT-11 (irinotecan) has a dose-limiting toxic effect of severe diarrhoea associated with pathological changes in the large and small intestines as well as haematological toxicities. In an earlier report, Hardman et al. 
Table 2. Experimental studies of the protective effects of $n-3$ fatty acids to the host during chemotherapy

\begin{tabular}{|c|c|c|c|c|}
\hline Author & Model & Drug & Design & Main findings \\
\hline $\begin{array}{l}\text { Hardman et al. } \\
\text { (1999) }\end{array}$ & $\begin{array}{l}\text { MCF-7 transplanted into } \\
\text { female Harlan Sprague-- } \\
\text { Dawley nude mice (nu/nu) }\end{array}$ & Irinotecan (CРT-11) & $\begin{array}{l}\text { Tumour bearing mice were } \\
\text { fed } 7 \% \text { maize oil }(n-6) \text {, } \\
4 \% \text { maize oil }+3 \% \text { fish oil or } \\
1 \% \text { maize oil }+6 \% \text { fish oil }\end{array}$ & $\begin{array}{l}\text { Increased CPT cytotoxicity } \\
\text { by fish oil; decreased intestinal } \\
\text { pathology with fish oil }\end{array}$ \\
\hline $\begin{array}{l}\text { Ogilvie et al. } \\
(2000)\end{array}$ & Dogs with lymphoma & DOX & $\begin{array}{l}\text { Dogs with lymphoma were fed } \\
\text { menhaden fish oil }+ \text { arginine or } \\
\text { soyabean oil (control) }\end{array}$ & $\begin{array}{l}\text { Increased number of disease-free } \\
\text { days and survival time for } \\
\text { stage III dogs but not stage IV; } \\
\text { increased survival time in dogs } \\
\text { with highest serum } 22: 6 n-3\end{array}$ \\
\hline $\begin{array}{l}\text { Bradley et al. } \\
(2001)\end{array}$ & $\begin{array}{l}\text { Madison } 109 \text { (M109) small- } \\
\text { cell lung tumours in CD2F1 } \\
\text { mice }\end{array}$ & $\begin{array}{l}\text { DHA-paclitaxel } \\
\text { conjugated with } \\
\text { EPA or paclitaxel }\end{array}$ & $\begin{array}{l}\text { Drugs were administered } \\
\quad \text { (intravenously) once daily for } 5 \mathrm{~d}\end{array}$ & $\begin{array}{l}\text { Decreased hind limb paralysis } \\
\text { with conjugate }\end{array}$ \\
\hline $\begin{array}{l}\text { Cha et al. } \\
(2002)\end{array}$ & $\begin{array}{l}\text { BDF1 mice injected with } \\
\text { L1210 leukaemia cells }\end{array}$ & Ara-C & $\begin{array}{l}\text { Mice were fed diets for } 14 \mathrm{~d} \\
\text { before tumour inoculation. } \\
\text { Animals were fed chow with } \\
\text { combinations of high and low } \\
\text { safflower-seed oil and high } \\
\text { and low DHA diets }\end{array}$ & $\begin{array}{l}\text { Beneficial effect on survival, } \\
\text { haematology and tumour burden } \\
\text { observed at low levels of } \\
\text { DHA; however, at plasma } \\
\text { concentrations of } 100 \mu \mathrm{M}-\mathrm{DHA} \\
\text { these beneficial effects were } \\
\text { reversed and increased host } \\
\text { toxicity and decreased tumour } \\
\text { cytotoxicity were observed }\end{array}$ \\
\hline $\begin{array}{l}\text { Hardman et al. } \\
\text { (2001) }\end{array}$ & $\begin{array}{l}\text { MDA-MB-231 transplanted } \\
\text { into Harlan Sprague-Dawley } \\
\text { nude mice (nu/nu) }\end{array}$ & DOX & $\begin{array}{l}\text { Tumour-bearing animals fed } 5 \% \\
\text { maize oil or } 2 \% \text { maize oil }+3 \% \\
\text { fish oil concentrate (34 \% EPA, } \\
24 \% \text { DHA, and } 10 \% \text { other } n-3)\end{array}$ & $\begin{array}{l}\text { Increased lipid peroxidation } \\
\text { by DOX + fish oil; decreased } \\
\text { tumour growth by DOX + fish } \\
\text { oil; decreased weight loss } \\
\text { with DOX + fish oil }\end{array}$ \\
\hline $\begin{array}{l}\text { Hardman et al. } \\
(2002)\end{array}$ & $\begin{array}{l}\text { Mice were provided diets for } \\
2 \text { weeks before delivering } \\
\text { chemotherapy }\end{array}$ & $\begin{array}{l}\text { Irinotecan } \\
\quad(\text { CPT-11) }\end{array}$ & $\begin{array}{l}\text { Mice were fed diets modified } \\
\text { to contain: } 10 \%(\mathrm{w} / \mathrm{w}) \text { maize oil } \\
+0 \% \text { AAFA }{ }^{\mathrm{TM} *}, 9 \% \text { maize } \\
\text { oil }+1 \% \text { AAFA } \\
+2 \% \text { AAFA }, 8 \% \text { maize oil } \\
\quad+2 \% \text { or } 7 \% \text { maize } \\
\text { oil }+3 \% \text { AAFA }\end{array}$ & $\begin{array}{l}2 \% \mathrm{AAFA}^{\mathrm{TM}} \text { in the diet of the } \\
\text { CPT-11-treated mice resulted in } \\
\text { reduced gastrointestinal } \\
\text { toxicities, prevented liver } \\
\text { hypertrophy, increased } \\
\text { enthrocyte leucocyte counts, } \\
\text { reduced haematological } \\
\text { toxicities and resulted in } \\
\text { maintenance of normal } \\
\text { grooming behaviour }\end{array}$ \\
\hline
\end{tabular}

DOX, doxorubicin; DHA, docosahexaenoic acid; EPA, eicosapentaenoic acid.

${ }^{*} \mathrm{AAFA}{ }^{\mathrm{TM}}$ is an $n-3$ fatty acid product that contains a total of $55 \%$ EPA plus DHA.

(1999) reported enhanced tumour regression by the coadministration of CPT-11 with fish oil and have subsequently reported fewer toxic effects to the host in the same model. Low-fat diets $(7 \%, \mathrm{w} / \mathrm{w})$ comprised of maize oil only, $3 \%$ or $6 \%$ fish oil were fed to tumour-bearing mice. Following irinotecan treatment, the intestinal physiology of the mice fed fish oil appeared similar to the mice who received no drug treatment whereas the mice fed maize-oil diets displayed considerable intestinal pathology (Hardman et al. 2000). A follow-up study employing $2 \%$ fish oil confirmed the protective effects of fish oil on gastrointestinal tissues (Hardman et al. 2002). The same investigators have reported similar findings using DOX as the cytotoxic agent (Hardman et al. 2001). Higher numbers of lymphocytes and erythrocytes and less weight loss were observed in tumourbearing mice fed a fish-oil concentrate at $3 \%$ compared with those fed a $5 \%$ maize-oil diet. Therefore, the gastrointestinal and haematological toxicities that limit the dose of these drugs appear to be attenuated when dietary fish oil accompanies the treatment.

One study has investigated the role of fish oil in relation to cardiac toxicity. Tumour-bearing rats fed $15 \%$ sardine oil were given epirubicin treatment with or without lipid peroxide inhibitors or inducers. The group receiving fish oil had significantly reduced growth and number of tumours, and no additional cardiac toxicity was observed (Germain et al. 1999).

While alopecia is not a dose-limiting toxic effect per se, it is a common side effect that is distressing to the patient and has few acceptable treatment options. Cytotoxic drugs designed to induce apoptosis in tumour cells also induce death in hair follicle cells resulting in hair loss. Alopecia induced by Ara-C and etoposide was prevented by the addition of DHA to the diet in an animal model. All animals not provided dietary DHA developed alopecia (Takahata et al. 1999).

While evidence from these few animal studies are generally positive, difficulty arises in the interpretation of studies where basal or control diets are either not representative of human diets or that, based on their fatty acid composition, would be expected to promote tumour progression. Maize oil has been commonly used as the source of fat in control diets in animal studies. While a maize-oil-based diet is not likely to induce an essential fatty acid deficiency per se, the 
skewed $n-6: n-3$ PUFA ratio in maize oil may be supportive of tumour growth or altered immune functions (Black et al. 1992; Rose \& Connolly, 1993; Simonsen et al. 1998; Klein et al. 2000; Furukawa et al. 2002; Calder, 2003). The balance of $n-6$ and $n-3$ PUFA rather than the total amount of fat consumed may be more important in determining cancer risk. A study employing 5 or $10 \%(\mathrm{w} / \mathrm{w})$ safflower-seed diets containing 1.5 or $3 \%(\mathrm{w} / \mathrm{w})$ DHA, respectively, reported reduced erythrocyte concentrations and lower survival when plasma levels of DHA reached $100 \mu \mathrm{M}$ (Cha et al. 2002). Conversely, benefits were seen at lower levels, suggesting that there may be an upper threshold limit for the beneficial effects of fish oil. In the one trial that fed dietary levels of fish oils that could be attained in man (Hardman et al. 2002), gastrointestinal toxicity was reduced; however, the control diet in that study was not relevant to man and, in fact, could be expected to promote inflammatory processes. Furthermore, the mechanisms of the drug in question and its interactions with specific nutrients may impact on the efficacy of fish oils. In the animal studies discussed, tumours were established before dietary intervention took place and drugs were administered some time afterwards. This design is of relevance to address supplementation as an adjuvant to therapy and may help address the question of whether long-chain PUFA may become conditionally essential during chemotherapy treatments. With several inter-related mechanisms proposed for the enhanced cytotoxic effects and protective host effects that potentially impact on many physiological systems, it would seem important to further clarify optimal conditions for growth inhibition and tissue protection that are relevant to the human situation.

\section{n-3 Polyunsaturated fatty acids alter catabolic signal transduction and attenuate wasting}

A majority of patients with advanced cancer experience a progressive syndrome of wasting known as cachexia. The end results of the wasting syndrome, emaciation and functional loss, remain hallmarks of advanced neoplastic disease. The wasting syndrome is typified by hyper-catabolism and accelerated degradation of skeletal muscle protein and adipose tissue which is often accompanied by anorexia, early satiety, weakness, anaemia, suppression of immune functions and oedema. Together with pain, cachexia is one of the most frequent and devastating symptoms that affect cancer patients. There have been a few reports of the inhibition of cancer-associated wasting by $n-3$ PUFA in animal models and clinical investigations. The idea of employing $n$-3 PUFA to attenuate protein catabolism in cancer-associated wasting syndromes is based on the understanding that systemic inflammation, cytokines and eicosanoids are central drivers of protein breakdown.

Research in animal models. Wasting has been attenuated in several animal models of cachexia by dietary fish oil supplementation (Table 3). Tisdale and co-workers have reported the suppression of wasting, muscle protein catabolism and muscle protease induction by feeding fish oil to mice bearing the MAC16 adenocarcinoma (Whitehouse et al. 2001; Tisdale, 2001). Similar effects have been shown for methylcholanthrene-induced sarcoma (Jho et al. 2002) and ApcMin/+ mice (Whelan et al. 2002). Tumour growth is inhibited by $n-3$ fatty acid supplementation in some models, and this would be expected to attenuate wasting indirectly (Whitehouse \& Tisdale, 2001; Jho et al. 2002). Although in some cases this may provide a partial explanation of reduced weight loss and tissue wasting, it seems clear that the anti-cachectic effect is larger than would be expected based on the magnitude of the reduction of tumour growth.

Mechanisms for attenuation of wasting by n-3 polyunsaturated fatty acids. The proposed mechanisms of attenuation of wasting by n-3 PUFA centre largely around catabolic signal transduction by cytokines, eicosanoids and tumour-derived proteolysis-inducing factor (PIF). The response of the body to cancer has many parallels with systemic inflammation (Argiles et al. 2000; Barber et al. 2000; Kotler, 2000; Wigmore et al. 2001). This has been very clearly resolved in animal models to significantly involve both cytokines and eicosanoids in cancer-associated wasting. The participation of pro-inflammatory cytokines including IL-1- $\beta$, IL-6, TNF- $\alpha$ and interferon- $\gamma$ has been positively established by changing cytokine production or activity using experimental approaches such as passive immunisation with antibodies to cytokines, cytokine receptor knockout mice, or animals over-expressing soluble receptor isoforms (Argiles \& Lopez-Soriano, 1999; Kotler, 2000; MacDonald et al. 2003).

Eicosanoids. Eicosanoids are key inflammatory mediators that have also been implicated in cancer cachexia (Ross \& Fearon, 2002). Eicosanoids appear to lie in the catabolic signal-transduction pathways of both cytokines and a tumour-derived proteolysis-inducing glycoprotein (Ross \& Fearon, 2002). Eicosanoids derived from $n$-3 PUFA have up to 100 -fold less biological potency in the induction of cellular responses than those derived from arachidonic acid and are usually associated with decreased inflammatory responses (Calder, 2003). Eicosanoids are produced by some tumours (Zweifel et al. 2002; Badawi \& Badr, 2003) as well as by the host during immune responses. Some of the evidence for the involvement of eicosanoids in the inflammatory process, which underlies cancer-associated wasting, has come from studies examining the action of non-steroidal anti-inflammatory drugs, including traditional non-steroidal anti-inflammatory drugs as well as agents developed to selectively block the synthesis of the inducible pro-inflammatory prostaglandins (Cahlin et al. 2000). Thus, one clear mechanism whereby n-3 PUFA might influence catabolism would be through modification of the eicosanoid axis resulting in a reduction in the inflammatory response. Alternatively, they may alter the production of eicosanoids involved in the signalling pathways of various catabolic mediators, such as the PIF (Lorite et al. 2001; Tisdale, 2003).

Proteolysis-inducing factor. Tumour-derived PIF is a novel molecule that mediates catabolism in mice bearing the MAC16 adenocarcinoma (Cariuk et al. 1997). This proteolysis-inducing glycoprotein of tumour origin consists of 
Table 3. $n$-3 Fatty acid effects on anorexia cachexia syndrome: animal and human studies

\begin{tabular}{|c|c|c|c|}
\hline Author & Cancer type & Study design & Main finding \\
\hline \multicolumn{4}{|l|}{ Animal studies } \\
\hline Smith et al. (1999) & Murine $\mathrm{C}_{2} \mathrm{C}_{12}$ myoblasts & $\begin{array}{l}\text { Effect of PIF in vitro and } \\
\text { modulation by EPA }\end{array}$ & $\begin{array}{l}\text { Decreased protein synthesis and degradation by PIF. } \\
\text { Pre-incubation with EPA inhibited protein degradation. } \\
\text { Increased arachidonate release, } \text { PGE }_{2}, \text { PGF2 } \alpha, 5-, 12-\text { and } \text { (5-HETE synthesis by PIF. 15-HETE identified as the } \\
\text { specific eicosanoid mediator of PIF }\end{array}$ \\
\hline Sauer et al. (2000) & $\begin{array}{l}\text { Hepatoma } 7288 C T C \text { cell } \\
\text { line implanted into } \\
\text { Buffalo rats }\end{array}$ & $\begin{array}{l}\text { Assessed for fatty acid } \\
\text { transport and 13-HODE } \\
\text { formation }\end{array}$ & $\begin{array}{l}\text { Decreased fatty acid uptake and release of } 13-\mathrm{HODE} \text { by EPA } \\
\text { Decreased }\left[{ }^{3} \mathrm{H}\right] \text {-thymidine incorporation by EPA. Addition } \\
\text { of } 13-\mathrm{HODE} \text {, forskolin, pertusis toxin and } 8-\mathrm{Br}-\mathrm{cAMP} \\
\text { reversed the inhibition by EPA. Receptor for } n-3 \text { fatty acids } \\
\text { is a G-protein involved in signalling via cAMP pathway }\end{array}$ \\
\hline
\end{tabular}

Islam-Ali et al. (2001) MAC16 adenocarcinoma Mice were or were not implanted into NMRI fed EPA

Human studies

Barber et al. (1999b) Weight-losing patients with advanced pancreatic cancer

Barber et al. (1999a) Weight-losing patients with advanced pancreatic cancer

Barber et al. (2001) Weight-losing patients with advanced pancreatic cancer

Bruera et al. (2003)

Weight-losing cancer patients of mixed tumour types

Burns et al. (1999) Weight-losing advanced cancer of mixed types

Wigmore et al. (2000) Weight-losing patients with advanced pancreatic cancer

Fearon et al. (2003) Weight-losing patients with advanced pancreatic cancer
Patients received two cans/d of a nutritional supplement enriched with $1.1 \mathrm{~g}$ EPA and $0.46 \mathrm{~g}$ DHA v. no supplement $v$. healthy controls

Patients received two cans/d of a nutritional supplement enriched with $1.1 \mathrm{~g}$ EPA and $0.46 \mathrm{~g} \mathrm{DHA} v$. no supplement $v$. healthy controls over 7 weeks

Patients consumed a nutritional supplement providing $2510 \mathrm{~kJ}$ $(600 \mathrm{kcal})$ and $2 \mathrm{~g}$ of

EPA per d for 3 weeks

Patients consumed $1.8 \mathrm{~g} \mathrm{EPA} / \mathrm{d}$ and $1.2 \mathrm{~g}$ $\mathrm{DHA} / \mathrm{d}$ as capsules for $14 \mathrm{~d}$

Maximum tolerable dosage of fish oil capsules $(378 \mathrm{mg}$ EPA and $249 \mathrm{mg}$ DHA) was determined

Patients consumed $95 \%$ EPA in capsules; $1 \mathrm{~g} / \mathrm{d}$ for 1 week, $2 \mathrm{~g} / \mathrm{d}$ in second week, and $4 \mathrm{~g} / \mathrm{d}$ in third week, and $6 \mathrm{~g} / \mathrm{d}$ thereafter

Patients instructed to consume two cans of a supplement providing $1300 \mathrm{~kJ}$ (310 kcal), $16 \mathrm{~g}$ protein, $6 \mathrm{~g}$ fat with or without $1.1 \mathrm{~g}$ EPA + antioxidants
Weight-losing mice had: lipid-mobilising factor; increased adenylate cyclase formation; expression $\mathrm{G}$ proteins. Treatment with EPA reduced $G$ protein ratio to normal

Increased weight in supplemented group (median $1 \mathrm{~kg}$ ); decreased weight in unsupplemented group (median $2.8 \mathrm{~kg}$ ); increased production of negative acute-phase proteins (albumin, pre-albumin and transferrin) in supplemented group suggesting an improvement in nutritional status and/or attenuation of acute-phase protein response

Patients consuming supplement exhibited increased weight gain over 7 weeks (median $2.5 \mathrm{~kg}$ ); decreased resting energy expenditure. No change in serum C-reactive protein concentrations. Increased Karnofsky performance and appetite scores

Decreased IL-6; increased serum insulin concentration; decreased cortisol:insulin ratio; decreased proportion of patients excreting proteolysis-inducing factor

No differences in weight loss, appetite, nutritional status or symptoms compared with placebo

Maximum tolerable dose as high as $0.3 \mathrm{~g} / \mathrm{kg}$ per day with minimal side effects (i.e. $21 \mathrm{~g} / \mathrm{d}$ for $70 \mathrm{~kg}$ individual)

Patients became weight stable with EPA supplementation, but no significant difference in energy intake was observed.

$6 \mathrm{~g}$ treatment did not appear to have a greater effect relative to a previous trial using $2 \mathrm{~g} / \mathrm{d}$

Weight loss was abrogated in both treatment groups.

Providing $n-3$ fatty acids resulted in weight gain, gain of lean tissue and improved quality of life 
a short polypeptide chain which is highly glycosylated. When muscle cells or animals are treated with the purified factor, intense protein catabolism is elicited (Cariuk et al. 1997; Lorite et al. 1998; Todorov et al. 1999). The mechanism of action of this factor is suggested to involve an eicosanoid, 15-HETE. The protein catabolism induced by PIF is markedly attenuated by the administration of EPA (Smith \& Tisdale, 2003; Tisdale, 2003). An identical factor found in man (Cabal-Manzano et al. 2001; Tisdale, 2001) appears to be present in a broad spectrum of cancer patients (i.e. carcinomas of the breast, lung, ovary, melanoma, gastrointestinal system) with active weight loss, but is absent in cancer patients who are not losing weight or in weightlosing patients with benign disease (Wigmore et al. 2000; Cabal-Manzano et al. 2001; Tisdale, 2001). These results possibly represent the discovery of a critical factor responsible for cancer cachexia in man. While several anti-inflammatory therapies exist that may be appropriate for cancer-associated cachexia (MacDonald et al. 2003), n-3 PUFA appear to intersect a number of pathways that would impart benefits to ameliorate the wasting syndrome.

\section{Safety and efficacy of n-3 polyunsaturated fatty acids in clinical trials}

n-3 PUFA are safe compounds. Safety was evaluated in a phase I trial, where participants with terminal cancer took up to $0 \cdot 3 \mathrm{~g} \mathrm{EPA} / \mathrm{kg}$ body weight, well beyond the $2-4 \mathrm{~g} / \mathrm{d}$ doses used in clinical trials (Burns et al. 1999). Even at high doses, side effects were relatively mild and included bloating, 'a fishy taste' and loose bowel movements. Similarly, early phase II trials conducted by Fearon and coworkers involving patients with pancreatic tumours not otherwise on chemotherapy receiving fish oil capsules were promising (Barber et al. 1999b; Wigmore et al. 2000). Significant improvements in weight, function and, to a lesser extent, appetite were reported. Of particular interest, in contrast to megestrol acetate, lean body mass increased. A randomised investigation of fish oil $v$. a maltodextrose placebo (Gogos et al. 1998) reported an improvement in survival and in immune function with an increase of the CD4:CD8 ratio (Gogos et al. 1998) in a mixed group of malnourished patients with generalised malignancy.

Following their series of phase II trials, Fearon and coworkers carried out a phase III double-blind randomised placebo-controlled trial, again enlisting weight-losing pancreatic cancer patients who had not undergone chemotherapy treatment. The source of $n-3$ in this study was a liquid enteral formula to be taken at a dose that would provide $2.2 \mathrm{~g}$ EPA and $0.9 \mathrm{~g}$ DHA. The control treatment was an isoenergetic, isonitrogenous supplement without EPA and DHA. An improvement in survival was not demonstrated in the $n$-3-treated group but, once again, these authors reported an improvement of lean body mass in those patients who were taking in excess of $1.5 \mathrm{~g}$ EPA daily (Barber \& Fearon, 2001). The most recent study from this group involved 200 patients with advanced pancreatic cancer (Fearon et al. 2003) randomised to the fish-oil-containing enteral supplement or an identical placebo containing n-6 fatty acids. Again, n-3 PUFA supplementation was associated with an increased lean body mass in a dose-dependent fashion.
A recently completed randomised, double-blind study was conducted cooperatively by the Northwest Clinical trials group NCI and NCI-Canada and this has been published as a preliminary report (Jatoi et al. 2003). These investigators compared the $n-3$ nutrient supplement used by Fearon's group (and the same placebo) with megestrol, and the two agents in combination, in an advanced cancer patient population. The EPA supplement scored as well as megestrol acetate on overall weight gain, survival and global quality of life; however the proportion of patients gaining $10 \%$ or more of body weight was higher in the patients receiving megestrol acetate alone. Changes in lean body mass were not investigated (Jatoi et al. 2003).

\section{Polyunsaturated fatty acid and $n-3$ status of the cancer patient}

The fatty acid status of cancer patients at diagnosis and throughout the disease trajectory has rarely been determined. Although a few studies have assessed nutritional status at select time-points during the disease (Table 3), no studies have systematically assessed changes in fatty acid status throughout the disease and/or treatment progression.

\section{At diagnosis}

Population studies illustrate the large variation of $n-3$ levels in blood and cell lipids in individuals from different countries and regions (de Deckere, 1999; Amiano et al. 2002; Augustsson et al. 2003; Terry et al. 2003). Thus it seems clear that any reports of PUFA status in cancer patients at any stage must be interpreted in the light of national or regional context. In a comprehensive review of intakes of fish and marine fatty acids in relation to hormone-related cancers, Terry et al. (2003) point out that the difference between the highest and lowest $n-3$ intakes internationally are as much as 15-fold (i.e. 1500,400 and $100 \mathrm{mg} / \mathrm{d}$ in Japan, Scandinavian countries and North America, respectively). The dietary $n-6: n-3$ fatty acids ratio shows a similar degree of variation.

The fatty acid status of patients at the time of a cancer diagnosis can be assumed to be a function of previous dietary intakes and the effect, if any, specific to disease and disease stage. Only one study to date has reported plasma fatty acid levels in patients with a new diagnosis of pancreatic, non-small-cell lung and stomach or oesophageal cancer (Zuijdgeest-van Leeuwen et al. 2002). The disease stage was not reported; however, up to $23 \%$ of patients had metastatic cancer at diagnosis. These were compared with normal healthy controls from a local population (The Netherlands). This report suggests impairments in essential fatty acid metabolism as the levels of fatty acids of the $n-6$ and $n-3$ series typically were lower than those of healthy subjects; however, the degree of difference and the specific fatty acids that are affected appear to vary between cancer types.

\section{During therapy}

Fatty acid metabolism and fatty acid status during treatment for cancer are not well characterised. In a pilot study by our group, we reported a selective depletion of long- 
chain PUFA in plasma and membrane phospholipid by a high-dose combination of cyclophosphamide, taxotere and 5-fluorouracil (MacDonald et al. 2003). Although preliminary, this study reported very low levels of long-chain PUFA (both $n-6$ and $n-3$ fatty acids) and markedly skewed $n-6: n-3$ ratios in plasma and cell phospholipid after cytotoxic treatment. Cytotoxic agents have been reported to interfere with the metabolism of PUFA (Marra et al. 1986) and may limit the endogenous production of EPA and DHA from $18: 3 n-3$, and of $20: 4 n-6$ from $18: 2 n-6$. It would seem important to examine the elongation and desaturation activity of 18-carbon fatty acids in cancer patients, as impairment of this function may result in the conditional essentiality of long-chain PUFA (Bordoni et al. 1999). The effects of various chemotherapies on fatty acid status need to be more fully documented and this may support an argument to attempt to increase PUFA levels before chemotherapy or to include supplementation with postchemotherapy re-alimentation. It seems possible that the depletion of PUFA is a side effect of chemotherapy that reduces $n-3$ status and thereby potentiates the side effects of subsequent cycles of chemotherapy, as well as inflammation and catabolic processes.

\section{At advanced disease stages}

Very little data have been collected on the fatty acid status of patients with advanced cancer. In a recent study (Pratt et al. 2002) we compared the fatty acid status of patients with advanced cancer with healthy subjects. Patients with locally recurrent or metastatic cancer of mixed primary sites were recruited from palliative care services. The median survival for the overall group was $14 \cdot 2$ (SE 1.9) weeks, reflecting a patient population with very advanced disease. Most strikingly, plasma phospholipids and most individual fatty acids in the phospholipids of advanced cancer patients were about $30 \%$ of the levels observed in healthy subjects with the essential fatty acids, $18: 2 n-6$ and $18: 3 n-3$, present in plasma phospholipid at 29 and $27 \%$ respectively. The mead acid (20:3n-9):20:4n-6 ratio, often used as an indicator of essential fatty acid deficiencies, was elevated in the cancer patients $(0.3(\mathrm{SE} 0.04) \mu \mathrm{g} / \mathrm{ml})$ compared with the healthy subjects (zero). In neutrophils, elevated arachidonic acid in all phospholipid classes was observed in patients with advanced cancer and contributed to a higher $n-6: n-3$ fatty acid ratio in these cells. These results suggest a potentially important depletion of $n-3$ and $n-6$ PUFA in advanced cancer and, within that, a tendency towards elevated $n-6: n$ 3 ratios, at least in neutrophils (Pratt et al. 2002).

While very limited in overall scope, these data suggest that the fatty acid status of patients newly diagnosed with cancer may be poor and that disease progression, poor dietary intakes and cytotoxic therapy all contribute to the progressive decline of fatty acid status during disease progression. In some cases, this may amount to a frank deficiency of essential fatty acids. In countries with low levels of marine fish in the diet and high $n-6$ fatty acid intakes, the fatty acid status may be enormously skewed towards $n-6$ fatty acids. A more comprehensive follow-up of fatty acid status of cancer patients throughout all stages of the disease trajectory is clearly warranted.

\section{Cautions, limitations and suggestions for further research}

What remains ambiguous in epidemiological studies has been clarified through experimental studies to define a role for $n-3$ fatty acids in reducing tumour growth. The mechanisms of action are now being described in precise biochemical and molecular terms. The advent of techniques that can dissect the response of genes to specific nutrients has created the potential for a clearer understanding of mechanisms and new targets of interventions in the coming future.

The role of $n$ - 3 fatty acids in mediating enhanced cytotoxicity and host protection remains an emerging field with several unanswered questions. While evidence from the few animal studies are generally positive, difficulty arises in drawing conclusions from studies where diets are not representative of human diets or that lack relevance to the human situation. Further studies must employ physiologically relevant diets and model clinical situations to clarify the role of $n$-3 PUFA in improving response to treatment. Furthermore, the mechanisms of the drug in question and its interactions with specific nutrients may impact on the efficacy of fish oils to increase toxic effects to the tumour while protecting the host tissues.

The optimal conditions for enhanced tumour death with host protection has not been well characterised due, in part, to the variety of experimental models that have been utilised. It appears, however, that the redox status of the host may be a factor in determining the efficacy of antineoplastic therapies. In light of this, further studies may emphasise a need for clearer nutritional recommendations to emerge for patients undergoing chemotherapy as many patients are self-prescribing antioxidant therapies before, during and after treatments. The impact this may have on the efficacy of the treatment in question is not known at this time. Clarification of these issues may be sought by adjusting the balance of pro-oxidants, such as fish oil, and antioxidants at different treatment stages in animal models that are appropriate human comparisons. With several inter-related mechanisms proposed for the enhanced cytotoxic effects and protective host effects that potentially impact on many physiological systems, it would seem important to further clarify the optimal conditions for these effects.

At present, little is known about the nutritional and fatty acid status of cancer patients at different points in the disease trajectory and this area is only beginning to be explored. It seems possible that the depletion of PUFA is a side effect of chemotherapy that reduces $n$-3 PUFA status and thereby potentiates the side effects of subsequent cycles of chemotherapy, as well as inflammation and catabolic processes. This makes one ponder if nutritional status and essential fatty acid status were 'optimal' at diagnosis, and could be maintained throughout serial therapies, improving tumour killing while experiencing fewer side effects. Assessments of nutritional status continuously from the time of presentation and diagnosis would greatly enhance studies investigating the role of nutritional status in relation to cancer and therapies. Furthermore, it is necessary to determine whether the long-chain n-3 PUFA 
become essential in the diet during cancer treatment, due to reduced de novo synthesis or increased utilisation.

A conclusion arising from experimental studies is that muscle wasting falls into distinct sub-types when considered at the level of humoral mediators (Baracos, 2000, 2001) which may very well be analogous to what occurs in cancer patients; however, the full profile of putative catabolic mediators in cancer cachexia has never been detailed in any cancer patient population. This may be important to discriminate between patients exhibiting different catabolic mechanisms during clinical assessment in order to apply appropriate interventions, and it would appear that $n-3$ PUFA status would be a key variable to include in clinical assessments.

Further exploration of the mechanisms of MDR, as well as cell growth and death regulators, will lead to the discovery of key subcellular targets for drug development and clarify the role of $n-3$ PUFA. Taking into account the many anti-tumour properties of $n$-3 PUFA, enhanced cytotoxicity of chemotherapeutic drugs to tumours and some evidence of protection to host tissues, $n-3$ fatty acid supplementation may be established as an effective adjuvant for current chemotherapy protocols.

The information on fatty acid status and fatty acid supplementation in patients with advanced cancer, taken together, provides a rationale for developing dietary recommendations based on formal assessments of fatty acid status and fatty acid requirements. This is particularly pertinent in countries where $n-3$ fatty acid intakes are generally low and $n-6: n-3$ ratios are high. Current intakes of total $n-3$ fatty acids are about $1.6 \mathrm{~g} / \mathrm{d}(0.7 \%$ of energy intake $)$ in the USA (Kris-Etherton et al. 2002). Of this, $\alpha$-linolenic acid accounts for about $1.4 \mathrm{~g} / \mathrm{d}$, and only $0 \cdot 1$ to $0 \cdot 2 \mathrm{~g} / \mathrm{d}$ comes from EPA and DHA. Formal population-based dietary recommendations for $n$ - 3 fatty acids have been made by the WHO and the North Atlantic Treaty Organization and also exist in several countries including Canada, Sweden, the UK, Australia and Japan. Typical recommendations for EPA+DHA are 0.3 to $0.5 \mathrm{~g} / \mathrm{d}$, and for $\alpha$-linolenic acid are $0 \cdot 8$ to $1 \cdot 1 \mathrm{~g} / \mathrm{d}$. Dietary reference intakes for energy and macronutrients were recently released by the Food and Nutrition Board, Institute of Medicine, and The National Academies (USA), in collaboration with Health Canada. These institutions placed the acceptable macronutrient distribution range for $\alpha$-linolenic acid at 0.6 to $1.2 \%$ of energy, or 1.3 to $2.7 \mathrm{~g} / \mathrm{d}$ on the basis of a $8370 \mathrm{~kJ}(2000$ kcal) diet (Kris-Etherton et al. 2002). This is nearly ten times the current intake of EPA+DHA of typical North Americans. In view of suggestions that the $n-3$ PUFA status in cancer patients may be even poorer than in the general population, it would appear obvious that dietary supplementation to maintain and replenish $n$-3 PUFA status at key points in the cancer disease trajectory is required. Dietary recommendations for such supplementation have not been adopted by cancer centres or agencies, and the number and type of supplements and $n$-3-containing products suited to the patient populations are very limited. For those wishing to advise upon or implement $n-3$ supplementation, the American Heart Association position paper on fish oil and $n$-3 fatty acid consumption (Kris-Etherton et al. 2002) is a useful reference.

\section{References}

Abulrob ANG, Mason M, Bryce R \& Gumbleton M (2000) The effect of fatty acids and analogues upon intracellular levels of doxorubicin in cells displaying P-glycoprotein mediated multidrug resistance. Journal of Drug Targeting 8, 247-256.

Amano H, Hayashi I, Endo H, Kitasato H, Yamashina S, Maruyama T, Kobayashi M, Satoh K, Narita M, Sugimoto Y, Murata T, Yoshimura H, Narumiya S \& Majima M (2003) Host prostaglandin E(2)-EP3 signaling regulates tumor-associated angiogenesis and tumor growth. Journal of Experimental Medicine 197, 221-232.

Amiano P, Dorronsoro M, Larranaga N, Renobales M \& Ruiz de Gordoa JC (2002) Very-long-chain omega-3 fatty acids as markers for habitual fish intake in Spain. IARC Scientific Publications 156, 201-202.

Arancia G, Molinari A, Calcabrini A, Meschini S \& Cianfriglia M (2001) Intracellular P-glycoprotein in multidrug resistant tumor cells. Italian Journal of Anatomy and Embryology 106, 59-68.

Argiles JM, Alvarez B, Carbo N, Busquets S, van Royen M \& Lopez-Soriano FJ (2000) The divergent effects of tumour necrosis factor-alpha on skeletal muscle: implications in wasting. European Cytokine Network 11, 552-559.

Argiles JM \& Lopez-Soriano FJ (1999) The role of cytokines in cancer cachexia. Medical Research Reviews 19, 223-248.

Augustsson K, Michaud DS, Rimm EB, Leitzmann MF, Stampfer MJ, Willett WC \& Giovannucci E (2003) A prospective study of intake of fish and marine fatty acids and prostate cancer. Cancer Epidemiology, Biomarkers and Prevention 12, 64-67.

Badawi AF \& Badr MZ (2003) Expression of cyclooxygenase-2 and peroxisome proliferator-activated receptor-gamma and levels of prostaglandin E2 and 15-deoxy-delta12,14-prostaglandin $\mathrm{J} 2$ in human breast cancer and metastasis. International Journal of Cancer 103, 84-90.

Baracos VE (2000) A panoply of anabolic and catabolic mediators. Current Opinion in Clinical Nutrition and Metabolic Care 3, 169-170.

Baracos VE (2001) A deadly combination of anorexia and hypermetabolism. Current Opinion in Clinical Nutrition and Metabolic Care 4, 175-177.

Barber MD, Fearon KC, Tisdale MJ, McMillan DC \& Ross JA (2001) Effect of a fish oil-enriched nutritional supplement on metabolic mediators in patients with pancreatic cancer cachexia. Nutrition and Cancer 40, 118-124.

Barber MD \& Fearon KCH (2001) Tolerance and incorporation of a high-dose eicosapentaenoic acid diester emulsion by patients with pancreatic cancer cachexia. Lipids 36, 347-351.

Barber MD, Ross JA \& Fearon KC (2000) Disordered metabolic response with cancer and its management. World Journal of Surgery 24, 681-689.

Barber MD, Ross JA, Preston T, Shenkin A \& Fearon KC (1999a) Fish oil-enriched nutritional supplement attenuates progression of the acute-phase response in weight-losing patients with advanced pancreatic cancer. Journal of Nutrition 129, 1120-1125.

Barber MD, Ross JA, Voss AC, Tisdale MJ \& Fearon KC (1999b) The effect of an oral nutritional supplement enriched with fish oil on weight-loss in patients with pancreatic cancer. British Journal of Cancer 81, 80-86.

Bartsch H, Nair J \& Owen RW (1999) Dietary polyunsaturated fatty acids and cancers of the breast and colorectum: emerging evidence for their role as risk modifiers. Carcinogenesis 20, 2209-2218.

Batist G, Tulpule A, Sinha BK, Katki AG, Myers CE \& Cowan KH (1986) Overexpression of a novel anionic glutathione transferase in multidrug-resistant human breast cancer cells. Journal of Biological Chemistry 261, 15544-15549. 
Birkenkamp-Demtroder K, Christensen LL, Olesen SH, Frederiksen CM, Laiho P, Aaltonen LA, Laurberg S, Sorensen FB, Hagemann R \& Orntoft TF (2002) Gene expression in colorectal cancer. Cancer Research 62, 4352-4363.

Black HS, Thornby JI, Gerguis J \& Lenger W (1992) Influence of dietary omega- $6,-3$ fatty acid sources on the initiation and promotion stages of photocarcinogenesis. Photochemistry and Photobiology 56, 195-199.

Bordoni A, Biagi PL \& Hrelia S (1999) The impairment of essential fatty acid metabolism as a key factor in doxorubicininduced damage in cultured rat cardiomyocytes. Biochimica et Biophysica Acta 1440, 100-106.

Bougnoux P (1999) n-3 Polyunsaturated fatty acids and cancer. Current Opinion in Clinical Nutrition and Metabolic Care 2, $121-126$.

Bradley MO, Webb NL, Anthony FH, Devanesan P, Witman PA, Hemamalini S, Chander MC, Baker SD, He LF, Horwitz SB \& Swindell CS (2001) Tumor targeting by covalent conjugation of a natural fatty acid to paclitaxel. Clinical Cancer Research 7, 3229-3238.

Bruera E, Strasser F, Palmer JL, Willey J, Calder K, Amyotte G \& Baracos VE (2003) Effect of fish oil on appetite and other symptoms in patients with advanced cancer and anorexia/cachexia: a double blind, placebo-controlled trial. Journal of Clinical Oncology 21, 129-134.

Burns CP, Halabi S, Clamon GH, Hars V, Wagner BA, Hohl RJ, Lester E, Kirshner JJ, Vinciguerra V \& Paskett E (1999) Phase I clinical study of fish oil fatty acid capsules for patients with cancer cachexia: cancer and leukemia group B study 9473 . Clinical Cancer Research 5, 3942-3947.

Cabal-Manzano R, Bhargava P, Torres-Duarte A, Marshall J, Bhargava P \& Wainer IW (2001) Proteolysis-inducing factor is expressed in tumours of patients with gastrointestinal cancers and correlates with weight loss. British Journal of Cancer 84, 1599-1601.

Cahlin C, Gelin J, Delbro D, Lonnroth C, Doi C \& Lundholm K (2000) Effect of cyclooxygenase and nitric oxide synthase inhibitors on tumor growth in mouse tumor models with and without cancer cachexia related to prostanoids. Cancer Research 60, 1742-1749.

Calder PC (2003) Long-chain n-3 fatty acids and inflammation: potential application in surgical and trauma patients. Brazilian Journal of Medical and Biological Research 36, 433-446.

Cariuk P, Lorite MJ, Todorov PT, Field WN, Wigmore SJ \& Tisdale MJ (1997) Induction of cachexia in mice by a product isolated from the urine of cachectic cancer patients. British Journal of Cancer 76, 606-613.

Cha MC, Meckling KA \& Stewart C (2002) Dietary docosahexaenoic acid levels influence the outcome of arabinosylcytosine chemotherapy in L1210 leukemic mice. Nutrition and Cancer 44, 176-181.

Cha SH, Fukushima A, Sakuma K \& Kagawa Y (2001) Chronic docosahexaenoic acid intake enhances expression of the gene for uncoupling protein 3 and affects pleiotropic mRNA levels in skeletal muscle of aged C57BL/6NJcl mice. Journal of Nutrition 131, 2636-2642.

Chajes V \& Bougnoux P (2003) Omega-6/omega-3 polyunsaturated fatty acid ratio and cancer. World Reviews of Nutrition and Dietetics 92, 133-151.

Chen ZY \& Istfan NW (2000) Docosahexaenoic acid is a potent inducer of apoptosis in HT-29 colon cancer cells. Prostaglandins Leukotrienes and Essential Fatty Acids 63, 301-308

Chen ZY \& Istfan NW (2001) Docosahexaenoic acid, a major constituent of fish oil diets, prevents activation of cyclin dependent kinases and S-phase entry by serum stimulation in HT-29 cells. Prostaglandins Leukotrienes and Essential Fatty Acids 64, 67-73.
Chung BH, Mitchell SH, Zhang JS \& Young CY (2001) Effects of docosahexaenoic acid and eicosapentaenoic acid on androgenmediated cell growth and gene expression in $\mathrm{LNCaP}$ prostate cancer cells. Carcinogenesis 22, 1201-1206.

Clarke RG, Lund EK, Latham P, Pinder AC \& Johnson IT (1999) Effect of eicosapentaenoic acid on the proliferation and incidence of apoptosis in the colorectal cell line HT29. Lipids 34, 1287-1295.

Clemens MR, Waladkhani AR, Bublitz K, Ehninger G \& Gey KF (1997) Supplementation with antioxidants prior to bone marrow transplantation. Wiener Klinische Wochenschrift 109, 771-776.

Cognault S, Jourdan ML, Germain E, Pitavy R, Morel E, Durand G, Bougnoux P \& Lhuillery C (2000) Effect of an alphalinolenic acid-rich diet on rat mammary tumor growth depends on the dietary oxidative status. Nutrition and Cancer 36, 33-41.

Cohen LA (2000) Re: Meta-analysis: dietary fat intake, serum estrogen levels, and the risk of breast cancer. Journal of the National Cancer Institute 92, 78.

Collett ED, Davidson LA, Fan YY, Lupton JR \& Chapkin RS (2001) n-6 and n-3 Polyunsaturated fatty acids differentially modulate oncogenic Ras activation in colonocytes. American Journal of Physiology 280, C1066-C1075.

Conklin KA (2002) Dietary polyunsaturated fatty acids: impact on cancer chemotherapy and radiation. Alternative Medicine Reviews 7, 4-21.

Connolly JM, Gilhooly EM \& Rose DP (1999) Effects of reduced dietary linoleic acid intake, alone or combined with an algal source of docosahexaenoic acid, on MDA-MB-231 breast cancer cell growth and apoptosis in nude mice. Nutrition and Cancer 35, 44-49.

Cowan KH, Batist G, Tulpule A, Sinha BK \& Myers CE (1986) Similar biochemical changes associated with multidrug resistance in human breast cancer cells and carcinogen-induced resistance to xenobiotics in rats. Proceedings of the National Academy of Sciences USA 83, 9328-9332.

Das UN, Madhavi N, Sravan KG, Padma M \& Sangeetha P (1998) Can tumour cell drug resistance be reversed by essential fatty acids and their metabolites? Prostaglandins Leukotrienes and Essential Fatty Acids 58, 39-54.

Das UN, Ramos EG \& Meguid MM (2003) Metabolic alterations during inflammation and its modulation by central actions of omega-3 fatty acids. Current Opinion in Clinical Nutrition and Metabolic Care 6, 413-419.

Davidson LA, Lupton JR, Jiang YH \& Chapkin RS (1999) Carcinogen and dietary lipid regulate ras expression and localization in rat colon without affecting farnesylation kinetics. Carcinogenesis 20, 785-791.

Davies CL, Loizidou M, Cooper AJ \& Taylor I (1999) Effect of gamma-linolenic acid on cellular uptake of structurally related anthracyclines in human drug sensitive and multidrug resistant bladder and breast cancer cell lines. European Journal of Cancer 35, 1534-1540.

de Deckere EA (1999) Possible beneficial effect of fish and fish n3 polyunsaturated fatty acids in breast and colorectal cancer. European Journal of Cancer Prevention 8, 213-221.

Dennis LK, Snetselaar LG, Nothwehr FK \& Stewart RE (2003) Developing a scoring method for evaluating dietary methodology in reviews of epidemiologic studies. Journal of the American Dietetic Association 103, 483-487.

Fan YY, McMurray DN, Ly LH \& Chapkin RS (2003) Dietary (n3 ) polyunsaturated fatty acids remodel mouse T-cell lipid rafts. Journal of Nutrition 133, 1913-1920.

Fearon KC, von Meyenfeldt MF, Moses AG, Van Geenen R, Roy A, Gouma DJ, Giacosa A, van Gossum A, Bauer J, Barber MD, Aaronson NK, Voss AC \& Tisdale MJ (2003) Effect of a protein and energy dense n-3 fatty acid enriched oral supplement on loss of weight and lean tissue in cancer cachexia: a randomised double blind trial. Gut 52, 1479-1486. 
Furukawa K, Yamamori H, Takagi K, Hayashi N, Suzuki R, Nakajima N \& Tashiro T (2002) Influences of soybean oil emulsion on stress response and cell-mediated immune function in moderately or severely stressed patients. Nutrition $\mathbf{1 8}$, $235-240$.

Germain E, Chajes V, Cognault S, Lhuillery C \& Bougnoux P (1998) Enhancement of doxorubicin cytotoxicity by polyunsaturated fatty acids in the human breast tumor cell line MDAMB-231: relationship to lipid peroxidation. International Journal of Cancer 75, 578-583.

Germain E, Lavandier F, Chajes V, Schubnel V, Bonnet P, Lhuillery C \& Bougnoux P (1999) Dietary n-3 polyunsaturated fatty acids and oxidants increase rat mammary tumor sensitivity to epirubicin without change in cardiac toxicity. Lipids $\mathbf{3 4}$, Suppl., S203.

Gogos CA, Ginopoulos P, Salsa B, Apostolidou E, Zoumbos NC \& Kalfarentzos F (1998) Dietary omega-3 polyunsaturated fatty acids plus vitamin E restore immunodeficiency and prolong survival for severely ill patients with generalized malignancy. Cancer 82, 395-402.

Goldstein LJ, Pastan I \& Gottesman MM (1992) Multidrug resistance in human cancer. Critical Reviews in Oncology and Hematology 12, 243-253.

Gottesman MM \& Pastan I (1993) Biochemistry of multidrug resistance mediated by the multidrug transporter. Annual Reviews of Biochemistry 62, 385-427.

Griffini P, Fehres O, Klieverik L, Vogels IM, Tigchelaar W, Smorenburg SM \& Van Noorden CJ (1998) Dietary omega-3 polyunsaturated fatty acids promote colon carcinoma metastasis in rat liver. Cancer Research 58, 3312-3319.

Hardman WE (2002) Omega-3 fatty acids to augment cancer therapy. Journal of Nutrition 132, 3508S-3512S.

Hardman WE, Avula CP, Fernandes G \& Cameron IL (2001) Three percent dietary fish oil concentrate increased efficacy of doxorubicin against MDA-MB 231 breast cancer xenografts. Clinical Cancer Research 7, 2041-2049.

Hardman WE, Moyer MP \& Cameron IL (1999) Fish oil supplementation enhanced CPT-11 (irinotecan) efficacy against MCF7 breast carcinoma xenografts and ameliorated intestinal sideeffects. British Journal of Cancer 81, 440-448.

Hardman WE, Moyer MP \& Cameron IL (2000) Dietary fish oil sensitizes A549 lung xenografts to doxorubicin chemotherapy. Cancer Letters 151, 145-151.

Hardman WE, Munoz J Jr \& Cameron IL (2002) Role of lipid peroxidation and antioxidant enzymes in omega 3 fatty acids induced suppression of breast cancer xenograft growth in mice. Cancer Cell International 2, 10.

Hong MY, Chapkin RS, Barhoumi R, Burghardt RC, Turner ND, Henderson CE, Sanders LM, Fan YY, Davidson LA, Murphy ME, Spinka CM, Carroll RJ \& Lupton JR (2002) Fish oil increases mitochondrial phospholipid unsaturation, upregulating reactive oxygen species and apoptosis in rat colonocytes. Carcinogenesis 23, 1919-1925.

Hong MY, Chapkin RS, Davidson LA, Turner ND, Morris JS, Carroll RJ \& Lupton JR (2003) Fish oil enhances targeted apoptosis during colon tumor initiation in part by downregulating Bcl-2. Nutrition and Cancer 46, 44-51.

Hrelia S, Bordoni A, Angeloni C, Leoncini E, Galina Toschi T, Lercker G \& Biagi PL (2002) Green tea extracts can counteract the modification of fatty acid composition induced by doxorubicin in cultured cardiomyocytes. Prostaglandins Leukotrienes and Essential Fatty Acids 66, 519-524.

Hughes-Fulford M, Chen Y \& Tjandrawinata RR (2001) Fatty acid regulates gene expression and growth of human prostate cancer PC-3 cells. Carcinogenesis 22, 701-707.

Islam-Ali B, Khan S, Price SA \& Tisdale MJ (2001) Modulation of adipocyte G-protein expression in cancer cachexia by a lipid- mobilizing factor (LMF). British Journal of Cancer $\mathbf{8 5}$, $758-763$

Iwamoto S, Senzaki H, Kiyozuka Y, Ogura E, Takada H, Hioki K \& Tsubura A (1998) Effects of fatty acids on liver metastasis of ACL-15 rat colon cancer cells. Nutrition and Cancer 31, $143-150$

Jatoi A, Rowland M, Loprinzi CL, Sloan JA, Dakhil SR, MacDonald N, Gagnon B, Novotny PJ, Malliard JA \& Krook JE (2003) An eicosapentaenoic acid (EPA)-enriched supplement versus megestrol acetate (MA) versus both for patients with cancer-associated wasting. A collaborative effort from the North Central Cancer Treatment Group (NCCTG) and the National Cancer Institute of Canada (NCIC). American Society of Clinical Oncology 22, 743.

Jho DH, Babcock TA, Tevar R, Helton WS \& Espat NJ (2002) Eicosapentaenoic acid supplementation reduces tumor volume and attenuates cachexia in a rat model of progressive nonmetastasizing malignancy. Journal of Parenteral and Enteral Nutrition 26, 291-297.

Jiang WG, Bryce RP \& Horrobin DF (1998) Essential fatty acids: molecular and cellular basis of their anti-cancer action and clinical implications. Critical Reviews Oncology/Hematology 27, 179-209.

Klein V, Chajes V, Germain E, Schulgen G, Pinault M, Malvy D, Lefrancq T, Fignon A, Le Floch O, Lhuillery C \& Bougnoux P (2000) Low alpha-linolenic acid content of adipose breast tissue is associated with an increased risk of breast cancer. European Journal of Cancer 36, 335-340.

Kotler DP (2000) Cachexia. Annals of Internal Medicine 133, 622-634.

Kris-Etherton PM, Harris WS \& Appel LJ (2002) Fish consumption, fish oil, omega-3 fatty acids, and cardiovascular disease. Circulation 106, 2747-2757.

Kumar GS \& Das UN (1995) Free radical-dependent suppression of growth of mouse myeloma cells by alpha-linolenic and eicosapentaenoic acids in vitro. Cancer Letters 92, 27-38.

Laviano A, Meguid MM \& Rossi-Fanelli F (2003) Cancer anorexia: clinical implications, pathogenesis, and therapeutic strategies. Lancet Oncology 4, 686-694.

Lavie Y, Fiucci G, Czarny M \& Liscovitch M (1999) Changes in membrane micordomains and caveolae constituents in multidrug-resistant cancer cells. Lipids 34, Suppl., S57-S63.

Lavie Y \& Liscovitch M (2000) Changes in lipid and protein constituents of rafts and caveolae in multidrug resistant cancer cells and their functional consequences. Glycoconjugate Journal 17, 253-259.

Liu G, Bibus DM, Bode AM, Ma WY, Holman RT \& Dong Z (2001) Omega 3 but not omega 6 fatty acids inhibit AP-1 activity and cell transformation in JB6 cells. Proceedings of the National Academy of Sciences USA 98, 7510-7515.

Liu P, Rudick M \& Anderson RGW (2002) Multiple functions of caveolin-1. Journal of Biological Chemistry 277, 41295-41298.

Liu QY \& Tan BK (2000) Effects of cis-unsaturated fatty acids on doxorubicin sensitivity in P388/DOX resistant and P388 parental cell lines. Life Sciences 67, 1207-1218.

Lorite MJ, Smith HJ, Arnold JA, Morris A, Thompson MG \& Tisdale MJ (2001) Activation of ATP-ubiquitin-dependent proteolysis in skeletal muscle in vivo and murine myoblasts in vitro by a proteolysis-inducing factor (PIF). British Journal of Cancer 85, 297-302.

Lorite MJ, Thompson MG, Drake JL, Carling G \& Tisdale MJ (1998) Mechanism of muscle protein degradation induced by a cancer cachectic factor. British Journal of Cancer 78, 850-856.

MacDonald N, Easson AM, Mazurak VC, Dunn GP \& Baracos VE (2003) Understanding and managing cancer cachexia. Journal of the American College of Surgeons 197, 143-161. 
McEntee MF \& Whelan J (2002) Dietary polyunsaturated fatty acids and colorectal neoplasia. Biomedical Pharmacotherapy 56, 380-387.

Mariadason JM, Arango D, Corner GA, Aranes MJ, Hotchkiss KA, Yang W \& Augenlicht LH (2002) A gene expression profile that defines colon cell maturation in vitro. Cancer Research 62, 4804.

Marra CA, de Alaniz MJ \& Brenner RR (1986) Modulation of delta 6 and delta 5 rat liver microsomal desaturase activities by dexamethasone-induced factor. Biochimica et Biophysica Acta 879, 388-393.

Meguid MM, Fetissov SO, Varma M, Sato T, Zhang L, Laviano A \& Rossi-Fanelli F (2000) Hypothalamic dopamine and serotonin in the regulation of food intake. Nutrition 16, 843-857.

Menendez JA, del Mar B, Montero S, Sevilla E, Escrich E, Solanas M, Cortes-Funes H \& Colomer R (2001) Effects of gamma-linolenic acid and oleic acid on paclitaxel cytotoxicity in human breast cancer cells. European Journal of Cancer 37, 402-413.

Mirnikjoo B, Brown SE, Chang WC, Morris JS, Wang N, Carroll RJ, Turner ND, Lupton JR \& Chapkin RS (2001) Protein kinase inhibition by omega-3 fatty acids. Journal of Biological Chemistry 276, 10888-10896.

Nair SS, Leitch J \& Garg ML (2001) n-3 Polyunsaturated fatty acid supplementation alters inositol phosphate metabolism and protein kinase $\mathrm{C}$ activity in adult porcine cardiac myocytes. Journal of Nutritional Biochemistry 12, 7-13.

Nakamura S \& Nishizuka Y (1994) Lipid mediators and protein kinase $\mathrm{C}$ activation for the intracellular signaling network. Journal of Biochemistry 115, 1029-1034.

Narayanan BA, Narayanan NK \& Reddy BS (2001) Docosahexaenoic acid regulated genes and transcription factors inducing apoptosis in human colon cancer cells. International Journal of Oncology 19, 1255-1262.

Narayanan BA, Narayanan NK, Simi B \& Reddy BS (2003) Modulation of inducible nitric oxide synthase and related proinflammatory genes by the omega-3 fatty acid docosahexaenoic acid in human colon cancer cells. Cancer Research 63, 972-979.

Ogilvie GK, Fettman MJ, Mallinckrodt CH, Walton JA, Hansen RA, Davenport DJ, Gross KL, Richardson KL, Rogers Q \& Hand MS (2000) Effect of fish oil, arginine, and doxorubicin chemotherapy on remission and survival time for dogs with lymphoma: a double-blind, randomized placebo-controlled study. Cancer 88, 1916-1928.

Palakurthi SS, Fluckiger R, Aktas H, Changolkar AK, Shahsafaei A, Harneit S, Kilic E \& Halperin JA (2000) Inhibition of translation initiation mediates the anticancer effect of the n-3 polyunsaturated fatty acid eicosapentaenoic acid. Cancer Research 60, 2919-2925.

Pandian SS, Sneddon AA, Bestwick CS, McClinton S, Grant I, Wahle KW \& Heys SD (2001) Fatty acid regulation of protein kinase $\mathrm{C}$ isoforms in prostate cancer cells. Biochemical and Biophysical Research Communications 283, 806-812.

Pasqualini ME, Heyd VL, Manzo P \& Eynard AR (2003) Association between E-cadherin expression by human colon, bladder and breast cancer cells and the 13-HODE:15-HETE ratio. A possible role of their metastatic potential. Prostaglandins Leukotrienes and Essential Fatty Acids 68, 9-16.

Pike LJ (2003) Lipid rafts: bringing order to chaos. Journal of Lipid Research 44, 655-667.

Pike LJ, Han X, Chung K-N \& Gross RW (2002) Lipid rafts are enriched in arachidonic acid and plasmenylethanolamine and their composition is independent of caveolin-1 expression: a quantitative electrospray ionization/mass spectrometric analysis. Biochemistry 41, 2075-2088.
Pratt VC, Watanabe S, Bruera E, Mackey J, Clandinin MT, Baracos VE \& Field CJ (2002) Plasma and neutrophil fatty acid composition in advanced cancer patients and response to fish oil supplementation. British Journal of Cancer 87, 1370-1378.

Ravagnan L, Roumier T \& Kroemer G (2002) Mitochondria, the killer organelles and their weapons. Journal of Cellular Physiology 192, 131-137.

Rhodes DR, Barrette TR, Rubin MA, Ghosh D \& Chinnaiyan AM (2002) Meta-analysis of microarrays: interstudy validation of gene expression profiles reveals pathway dysregulation in prostate cancer. Cancer Research 62, 4427-4433.

Robinson LE, Clandinin MT \& Field CJ (2001) R3230AC rat mammary tumor and dietary long-chain (n-3) fatty acids change immune cell composition and function during mitogen activation. Journal of Nutrition 131, 2021-2027.

Rose DP \& Connolly JM (1993) Effects of dietary omega-3 fatty acids on human breast cancer growth and metastases in nude mice. Journal of the National Cancer Institute 85, 1743-1747.

Rose DP \& Connolly JM (1999a) Antiangiogenicity of docosahexaenoic acid and its role in the suppression of breast cancer cell growth in nude mice. International Journal of Oncology 15, 1011-1015.

Rose DP \& Connolly JM (1999b) Omega-3 fatty acids as cancer chemopreventive agents. Pharmacology and Therapeutics $\mathbf{8 3}$ 217-244

Rose DP \& Connolly JM (2000) Regulation of tumor angiogenesis by dietary fatty acids and eicosanoids. Nutrition and Cancer 37, 119-127.

Ross JA \& Fearon KC (2002) Eicosanoid-dependent cancer cachexia and wasting. Current Opinion in Clinical Nutrition and Metabolic Care 5, 241-248.

Rudra PK \& Krokan HE (2001) Cell-specific enhancement of doxorubicin toxicity in human tumour cells by docosahexaenoic acid. Anticancer Research 21, 29-38.

Sasaki T, Kobayashi Y, Shimizu J, Wada M, In'nami S, Kanke Y \& Takita T (1998) Effects of dietary n-3-to-n-6 polyunsaturated fatty acid ratio on mammary carcinogenesis in rats. Nutrition and Cancer 30, 137-143.

Sauer LA, Dauchy RT \& Blask DE (2000) Mechanism for the antitumor and anticachectic effects of n-3 fatty acids. Cancer Research 60, 5289-5295.

Senchenkov A, Litvak DA \& Cabot MC (2001) Targeting ceramide metabolism - a strategy for overcoming drug resistance. Journal of the National Cancer Institute 93, 347-357.

Senzaki H, Iwamoto S, Ogura E, Kiyozuka Y, Arita S, Kurebayashi J, Takada H, Hioki K \& Tsubura A (1998) Dietary effects of fatty acids on growth and metastasis of KPL-1 human breast cancer cells in vivo and in vitro. Anticancer Research 18 1621-1627.

Shappell SB, Olson SJ, Hannah SE, Manning S, Roberts RL, Masumori N, Jisaka M, Boeglin WE, Vader V, Dave DS, Shook MF, Thomas TZ, Funk CD, Brash AR \& Matusik RJ (2003) Elevated expression of 12/15-lipoxygenase and cyclooxygenase-2 in a transgenic mouse model of prostate carcinoma. Cancer Research 63, 2256-2267.

Siddiqui RA, Jenski LJ, Neff K, Harvey K, Kovacs RJ \& Stillwell W (2001) Docosahexaenoic acid induces apoptosis in Jurkat cells by a protein phosphatase-mediated process. Biochimica et Biophysica Acta 1499, 265-275.

Sidorenko I, Frantsiiants EM, Tkacheva EM, Musienko NV \& Kartashov SZ (1998) The effect of chemotherapeutic drugs on free-radical oxidation of lipids in the lymph of lung cancer patients (in Russian). Voprosy Onkologii 44, 297-299.

Siegfried JM, Burke TG \& Tritton TR (1985) Cellular transport of anthracyclines by passive diffusion. Implications for drug resistance. Biochemistry and Pharmacology 34, 593-598.

Sikic BI (1997) Pharmacologic approaches to reversing multidrug resistance. Seminars in Hematology 34, 40-47. 
Simonsen N, van't Veer P, Strain JJ, Martin-Moreno JM, Huttunen JK, Navajas JF, Martin BC, Thamm M, Kardinaal AF, Kok FJ \& Kohlmeier L (1998) Adipose tissue omega-3 and omega-6 fatty acid content and breast cancer in the EURAMIC study. European Community Multicenter Study on Antioxidants, Myocardial Infarction, and Breast Cancer. American Journal of Epidemiology 147, 342-352.

Simopoulos AP (1999) Evolutionary aspects of omega-3 fatty acids in the food supply. Prostaglandins Leukotrienes and Essential Fatty Acids 60, 421-429.

Simopoulos AP (2002) Omega-3 fatty acids in inflammation and autoimmune diseases. Journal of the American College of Nutrition 21, 495-505.

Smith HJ, Lorite MJ \& Tisdale MJ (1999) Effect of a cancer cachectic factor on protein synthesis/degradation in murine $\mathrm{C} 2 \mathrm{C} 12$ myoblasts: modulation by eicosapentaenoic acid. Cancer Research 59, 5507-5513.

Smith HJ \& Tisdale MJ (2003) Induction of apoptosis by a cachectic-factor in murine myotubes and inhibition by eicosapentaenoic acid. Apoptosis 8, 161-169.

Spector AA \& Burns CP (1987) Biological and therapeutic potential of membrane lipid modification in tumors. Cancer Research 47, 4529-4537.

Stoll BA (2001) $n$-3 Fatty acids and lipid peroxidation in breast cancer inhibition. British Journal of Nutrition 87, 193-198.

Stulnig TM, Berger M, Sigmund T, Raederstorff D, Stockinger H \& Waldhausl W (1998) Polyunsaturated fatty acids inhibit T cell signal transduction by modification of detergent-insoluble membrane domains. Journal of Cell Biology 143, 637-644.

Stulnig TM, Huber J, Leitinger N, Imre E-M, Angelisova P, Nowotny P \& Waldhausl W (2001) Polyunsaturated eicosapentaenoic acid displaces proteins from membrane rafts by altering raft lipid composition. Journal of Biological Chemistry 276, 37335-37340.

Swinnen JV, Van Veldhoven PP, Timmermans L, De Schrijver E, Brusselmans K, Vanderhoydonc F, Van de Sande T, Heemers H, Heyns W \& Verhoeven G (2003) Fatty acid synthase drives the synthesis of phospholipids partitioning into detergent-resistant membrane microdomains. Biochemical and Biophysical Research Communications 21, 898-903.

Takahata K, Tada M, Yazawa K \& Tamaki T (1999) Protection from chemotherapy-induced alopecia by docosahexaenoic acid. Lipids 34, Suppl., S105.

Temple NJ (2002) Nutrition and disease: challenges of research design. Nutrition 18, 343-347.

Terry PD, Rohan TE \& Wolk A (2003) Intakes of fish and marine fatty acids and the risks of cancers of the breast and prostate and of other hormone-related cancers: a review of the epidemiologic evidence. American Journal of Clinical Nutrition $\mathbf{7 7}$, 532-543.

Theile A \& Kemper P (1998) Bleomycin-induced pulmonary fibrosis following chemotherapy of ovarian granulosa cell tumor (in German). Pneumologie 52, 325-332.

Thoennes SR, Tate PL, Price TM \& Kilgore MW (2000) Differential transcriptional activation of peroxisome proliferator-activated receptor gamma by omega- 3 and omega- 6 fatty acids in MCF-7 cells. Molecular and Cellular Endocrinology 160, 67-73.

Tisdale MJ (2001) Loss of skeletal muscle in cancer: biochemical mechanisms. Frontiers in Bioscience 6, D164-D174.

Tisdale MJ (2003) The 'cancer cachectic factor'. Supportive Care in Cancer 11, 73-78.

Todorov PT, Field WN \& Tisdale MJ (1999) Role of a proteolysis-inducing factor (PIF) in cachexia induced by a human melanoma (G361). British Journal of Cancer 80, 1734-1737.

Tsuji M, Murota S \& Morita I (2003) Docosapentaenoic acid (22:5, n-3) suppressed tube-forming activity in endothelial cells induced by vascular endothelial growth factor. Prostaglandins Leukotrienes and Essential Fatty Acids 68, 337-342.

Verstovsek G, Byrd A, Frey MR, Petrelli NJ \& Black JD (1998) Colonocyte differentiation is associated with increased expression and altered distribution of protein kinase $\mathrm{C}$ isozymes. Gastroenterology 115, 75-85.

Wahle KWJ \& Heys SD (2002) Cell signal mechanisms, conjugated linoleic acids (CLAs) and anti-tumorigenesis. Prostaglandins Leukotrienes and Essential Fatty Acids 67, 183-186.

Wang H, Storlien LH \& Huang XF (2002) Effects of dietary fat types on body fatness, leptin, and ARC leptin receptor, NPY, and AgRP mRNA expression. American Journal of Physiology 282, E1352-E1359.

Weisburger JH (2000) Prevention of cancer and other chronic diseases worldwide based on sound mechanisms. Biofactors 12, 73-81.

Whelan J, Petrik MB, McEntee MF \& Obukowicz MG (2002) Dietary EPA reduces tumor load in ApcMin/+ mice by altering arachidonic acid metabolism, but conjugated linoleic acid, gamma- and alpha-linolenic acids have no effect. Advances in Experimental Medicine and Biology 507, 579-584.

Whitehouse AS, Smith HJ, Drake JL \& Tisdale MJ (2001) Mechanism of attenuation of skeletal muscle protein catabolism in cancer cachexia by eicosapentaenoic acid. Cancer Research 61, 3604-3609.

Whitehouse AS \& Tisdale MJ (2001) Downregulation of ubiquitin-dependent proteolysis by eicosapentaenoic acid in acute starvation. Biochemical and Biophysical Research Communications 285, 598-602.

Wigmore SJ, Barber MD, Ross JA, Tisdale MJ \& Fearon KC (2000) Effect of oral eicosapentaenoic acid on weight loss in patients with pancreatic cancer. Nutrition and Cancer 36, 177-184.

Wigmore SJ, McMahon AJ, Sturgeon CM \& Fearon KC (2001) Acute-phase protein response, survival and tumour recurrence in patients with colorectal cancer. British Journal of Surgery 88, 255-260

Woods JM, Mogollon A, Amin MA, Martinez RJ \& Koch AE (2003) The role of COX-2 in angiogenesis and rheumatoid arthritis. Experimental and Molecular Pathology 74, 282-290.

Woutersen RA, Appel MJ, Garderen-Hoetmer A \& Wijnands MV (1999) Dietary fat and carcinogenesis. Mutation Research 443, 111-127.

Yam D, Peled A \& Shinitzky M (2001) Suppression of tumor growth and metastasis by dietary fish oil combined with vitamins $\mathrm{E}$ and $\mathrm{C}$ and cisplatin. Cancer Chemotherapy and Pharmacology 47, 34-40.

Yamamoto D, Kiyozuka Y, Adachi Y, Takada H, Hioki K \& Tsubura A (1999) Synergistic action of apoptosis induced by eicosapentaenoic acid and TNP-470 on human breast cancer cells. Breast Cancer Research and Treatment 55, 149-160.

Yamauchi T, Watanabe M, Hasegawa H, Nishibori H, Ishii Y, Tatematsu H, Yamamoto K, Kubota T \& Kitajima M (2003) The potential for a selective cyclooxygenase- 2 inhibitor in the prevention of liver metastasis in human colorectal cancer. Anticancer Research 23, 245-249.

Zock PL (2001) Dietary fats and cancer. Current Opinion in Lipidology 12, 5-10.

Zuijdgeest-van Leeuwen SD, van der Heijden MS, Rietveld T, van den Berg JWO, Tilanus HW, Burgers JA, Paul Wilson JH \& Dagnelie PC (2002) Fatty acid composition of plasma lipids in patients with pancreatic, lung and oesophageal cancer in comparison with healthy subjects. Clinical Nutrition 21, 225-230.

Zweifel BS, Davis TW, Ornberg RL \& Masferrer JL (2002) Direct evidence for a role of cyclooxygenase 2-derived prostaglandin E2 in human head and neck xenograft tumors. Cancer Research 62, 6706-6711. 